\title{
Mercury fluxes from volcanic and geothermal sources: An update
}

Article in Geological Society London Special Publications · August 2014

DOI: $10.1144 /$ SP 410.2

CITATIONS

28

8 authors, including:

Emanuela Bagnato

Università degli Studi di Perugia

47 PUBLICATIONS 846 CITATIONS

SEE PROFILE

Geoffroy Avard

National University of Costa Rica

64 PUBLICATIONS 544 CITATIONS

SEE PROFILE

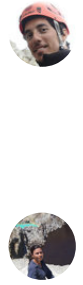

Giancarlo Tamburello

National Institute of Geophysics and Volcanology

106 PUBLICATIONS 1,439 CITATIONS

SEE PROFILE

Maria Martinez Cruz

National University of Costa Rica

102 PUBLICATIONS 495 CITATIONS

SEE PROFILE

Some of the authors of this publication are also working on these related projects:

Reconocimiento del sistema kárstico de Venado de San Carlos y sus implicaciones espeleológicas, hidrogeológicas, geológicas y geoturísticas View project

Distributions and transport of atmospheric mercury in China View project 
Geological Society, London, Special Publications Online First

\section{Mercury fluxes from volcanic and geothermal sources: an update}

E. Bagnato, G. Tamburello, G. Avard, M. Martinez-Cruz, M. Enrico, X. Fu, M. Sprovieri and J. E. Sonke

Geological Society, London, Special Publications, first published August 1, 2014; doi 10.1144/SP410.2

$\begin{array}{ll}\begin{array}{l}\text { Email alerting } \\ \text { service }\end{array} & \begin{array}{l}\text { click here to receive free e-mail alerts when } \\ \text { new articles cite this article }\end{array} \\ \begin{array}{l}\text { Permission } \\ \text { request }\end{array} & \begin{array}{l}\text { click here to seek permission to re-use all or } \\ \text { part of this article }\end{array} \\ \text { Subscribe } & \begin{array}{l}\text { click here to subscribe to Geological Society, } \\ \text { London, Special Publications or the Lyell } \\ \text { Collection }\end{array}\end{array}$

How to cite click here for further information about Online First and how to cite articles

Notes 


\title{
Mercury fluxes from volcanic and geothermal sources: an update
}

\author{
E. BAGNATO ${ }^{*}$, G. TAMBURELLO ${ }^{1}$, G. AVARD ${ }^{2}$, M. MARTINEZ-CRUZ ${ }^{2}$, M. ENRICO ${ }^{3}$, \\ X. FU ${ }^{3}$, M. SPROVIERI ${ }^{4} \&$ J. E. SONKE ${ }^{3}$ \\ ${ }^{1}$ DiSTeM, University of Palermo, Via Archirafi, 36, 90123 Palermo, Italy \\ ${ }^{2}$ Observatorio Vulcanológico y Sismológico de Costa Rica, Universidad Nacional, \\ 2346-3000 Heredia, Costa Rica \\ ${ }^{3}$ Observatoire Midi-Pyrénées, CNRS-GET, 14, avenue Edouard Belin, 31400 Toulouse, France \\ ${ }^{4}$ IAMC-CNR, Via del Mare 3, 91021 Torretta Granitola, Mazara del Vallo (TP), Italy \\ *Corresponding author (e-mail: emanuelabagnato@virgilio.it)
}

\begin{abstract}
We review the state of knowledge on global volcanogenic $\mathrm{Hg}$ emissions to the atmosphere and present new data from seven active volcanoes (Poás, Rincón de la Vieja, Turrialba, Aso, Mutnovsky, Gorely and Etna) and two geothermal fields (Las Pailas and Las Hornillas). The variability of $\mathrm{Hg}$ contents $\left(c .4-125 \mathrm{ng} \mathrm{m}^{-3}\right.$ ) measured in gaseous emissions reflects the dynamic nature of volcanic plumes, where the abundances of volatiles are determined by the physical nature of degassing and variable air dilution. Based on our dataset and previous work, we propose that an average $\mathrm{Hg} / \mathrm{SO}_{2}$ plume mass ratio of $c .7 .8 \times 10^{-6}\left( \pm 1.5 \times 10^{-6} ; 1 \mathrm{SE}, n=13\right)$ is best representative of open-conduit quiescent degassing. Taking into account the uncertainty in global $\mathrm{SO}_{2}$ emissions, we infer a global volcanic $\mathrm{Hg}$ flux from persistent degassing of $c .76 \pm 30 \mathrm{t} \mathrm{a}^{-1}$. Our data are derived from active volcanoes during non-eruptive periods and we do not have any direct constraint on the $\mathrm{Hg}$ flux during periods of elevated $\mathrm{SO}_{2}$ flux associated with large-scale effusive or explosive eruptions. This suggests that the time-averaged $\mathrm{Hg}$ flux from these volcanoes is even larger if the eruptive contribution is considered. Conversely, closed-conduit degassing and geothermal emissions contribute modest amounts of $\mathrm{Hg}$.
\end{abstract}

A significant amount of heavy metals is emitted into the atmosphere from natural (volcanoes, soil, seawater, etc.) and anthropogenic (industrial and mining activities, fossil fuel combustion, etc.) sources. Volatile emissions in passively or eruptive magmatic degassing volcanoes, fumaroles and geothermal fields influence the composition of the atmosphere and global climate, and impact the biogeochemical cycles of a number of trace elements (e.g. Robock \& Oppenheimer 2003; Wallace 2005). Knowledge of the contribution of volcanic degassing systems and geothermal fields to the global budgets of heavy metals in the Earth's atmosphere is essential to evaluate the role that the volcanoes play on the reservoir cycling of these elements and the potential fates they could represent once they reach the ecosystems. Volcanic emissions are the major natural source of several trace metals (e.g. As, Cd, Cu, Pb, Zn, Tl, Sb and $\mathrm{Sn}$ ) to the atmosphere by contributing $20-40 \%$ of volatile elements such as $\mathrm{Bi}, \mathrm{Pb}$, As or $\mathrm{Sb}$ and up to $40-50 \%$ of $\mathrm{Cd}$ annually (Hinkley et al. 1999; Martínez 2008; Mather et al. 2012; Henley \& Berger 2013). However, current research on trace element emissions from active volcanism shows that the magnitude of some element fluxes is still highly uncertain. This is the case for atmospheric mercury $(\mathrm{Hg})$ which is a key contaminant in biochemical processes as well as in air, water and soils, for which volcanism may be an important natural contributor (Varekamp \& Buseck 1986; Nriagu \& Becker 2003; Pyle \& Mather 2003; Bagnato et al. 2007, 2011; Martin et al. 2012). In volcanic plume gaseous elemental mercury $\left(\mathrm{Hg}^{0}\right.$ or GEM) is the dominant species ( $\geq 90 \%$; Slemr et al. 1985 ; Schroeder \& Munthe 1998; Bagnato et al. 2007; von Glasgow 2010; Martin et al. 2011) with an atmospheric lifetime of c. 0.5-1 a (Lindqvist and Rodhe 1985; Slemr et al. 1985; Lindberg et al. 2007; Aryia et al. 2008), allowing it to be transported to great distances from the source. The relative proportions of gaseous $\mathrm{Hg}_{(\mathrm{g})}^{0}$ and $\mathrm{Hg}(\mathrm{II})$ species in volcanic gas plumes, and the ratio of gaseous to particulate $\mathrm{Hg}$ forms, have rarely been determined in a systematic way (Bagnato et al. 2007; Witt et al. 2008a, $b$ ). Once deposited in surface waters, $\mathrm{Hg}$ is assimilated and processed by the biosphere that converts the relatively inert inorganic $\mathrm{Hg}$ into toxic methylated forms which can bioaccumulate in the food chain (Morel et al. 1998).

The current estimate of $\mathrm{Hg}$ emissions from natural processes (primary mercury emissions + re-emissions), is estimated to be $5207 \mathrm{t} \mathrm{a}^{-1}$ which represents nearly $70 \%$ of the global mercury 


\section{E. BAGNATO ET AL.}

emission budget (Pirrone et al. 2010). Overall, the relative contribution of terrestrial surfaces is $2429 \mathrm{t} \mathrm{a}^{-1}$ (47\% of the total natural emissions) and that from surface waters is $2778 \mathrm{t} \mathrm{a}^{-1}$ (53\% of the total natural emissions) (Pirrone et al. 2010). Significant research has been published over the last 10 years quantifying and demonstrating the importance of emissions from volcanoes and $\mathrm{Hg}$ enriched substrates ( $>100 \mathrm{ppb} \mathrm{Hg}$ ) (Friedli et al. 2003; Gustin 2003; Pyle \& Mather 2003; Bagnato et al. 2007, 2011; Gustin et al. 2008). Earlier and more recent studies proposed that cataclysmic volcanic eruptions would have the potential to inject volatile $\mathrm{Hg}$ into the stratosphere (Delmas et al. 1992; Langway et al. 1995; Robock \& Free 1995; Schuster et al. 2002) to change its global and regional cycle for a few years. In contrast, quiescent degassing and moderate eruptions exhale directly into the troposphere and can have long-term effects on local environments.

Regionally, a single persistently active volcano may act as the most important local point source (e.g. $\mathrm{SO}_{2}$ emissions from Etna volcano, Sicily, to the Mediterranean and Western Europe; Simpson et al. 1999; Bagnato et al. 2007). However important, there are currently many difficulties in quantifying the $\mathrm{Hg}$ flux from volcanic emissions due to the spatial and temporal variability in the activity from one volcano to another (Ferrara et al. 2000; Bagnato et al. 2011), or from different emission points on the volcano being studied (Dedeurwaerder et al. 1982; Bagnato et al. 2007). Due to the logistical restrictions of acquiring measurements at volcanoes (difficulty of access, limited power supply, etc.), $\mathrm{Hg}$ measurements often only comprise few data points. Two recent reviews narrow down previous estimates of volcanic $\mathrm{Hg}$ emission fluxes of 0.6-830 $\mathrm{t} \mathrm{a}^{-1}$ (Varekamp \& Buseck 1986; Nriagu \& Pacyna 1988; Ferrara et al. 2000) to $90 \mathrm{t} \mathrm{a}^{-1}$ and $700 \mathrm{t} \mathrm{a}^{-1}$ (Pyle \& Mather 2003; Pirrone et al. 2010). Volcanic $\mathrm{Hg}$ emissions may therefore represent c. $4-28 \%$ of natural primary emissions (Pirrone et al. 2010).

The large variability of these estimates partly reflects the complexity of the chemical and physical processes that $\mathrm{Hg}$ undergoes while interacting with the atmosphere. Most of the $\mathrm{Hg}$ observations used in previous inventories are derived from spot measurements taken from a few volcanoes, and there is much concern over the different methods in which different authors have attempted to assess $\mathrm{Hg}$ fluxes. All of these limitations may explain the large uncertainties in extrapolating data to global $\mathrm{Hg}$ emissions. Finally, the knowledge of $\mathrm{Hg}$ emissions from geothermal sources is still poorly investigated; they are therefore often considered as a negligible contributor to the atmosphere.
The objective of this work is to extend and refine the currently limited volcanic $\mathrm{Hg}$ dataset. We present here new $\mathrm{Hg}$ data for seven active volcanoes (Aso, Turrialba, Poás, Rincón de la Vieja, Etna, Gorely and Mutnovsky) and two important geothermal systems (Las Paillas and Las Hornillas, Costa Rica). We evaluate previous work on volcanic $\mathrm{Hg}$ fluxes, and combine the new data with the few relevant estimates of $\mathrm{Hg}$ fluxes from previous direct measurements on volcanic plumes to develop a realistic assessment of time-averaged volcanic $\mathrm{Hg}$ fluxes. Conventional gold-trap sampling and Lumex ${ }^{\circledR} /$ MultiGAS GPS-synchronized surveys were carried out to obtain real-time measurements of $\mathrm{Hg}$ and major volatiles in the fumes of the investigated volcanoes. These measurements, the first carried out at such locations, extend previous combined Lumex ${ }^{\circledR} /$ MultiGAS surveys reported elsewhere (Aiuppa et al. 2007; Witt et al. 2008a, $b$; Bagnato et al. 2013), and aim at improving our understanding of the magmatic systems and its degassing budget.

\section{Materials and methods}

\section{Study areas}

Measurements were carried out on the crater rim of seven quiescently degassing volcanoes and in two active geothermal areas with various surface manifestations. The study sites that are reported on here are located together with other locations discussed in the text in Figure 1. Aso volcano, in the central part of Kyushu Island $\left(32^{\circ} 53^{\prime} 6.36^{\prime \prime} \mathrm{N}, 131^{\circ} 5^{\prime}\right.$ $7.44^{\prime \prime}$ ), Japan is an active volcano with a c. $20 \mathrm{~km}$ diameter caldera that has some post-caldera central cones, including Mt Nakadake, where the current activity is mainly concentrated. The crater contains one of the hottest and most acidic volcanic lakes, with water temperature in the range $40-80{ }^{\circ} \mathrm{C}$ and acidity levels of $\mathrm{pH}-1$ to +1 during calm periods (Ohsawa et al. 2003, 2010; Terada \& Sudo 2012). Low-temperature gases are emitted from the lake surface, and intense active high-temperature gas emissions (approximately $800{ }^{\circ} \mathrm{C}$ ) are produced by fumaroles on the southern crater wall (Shinohara et al. 2010, 2013).

Gorely, Russia $\left(52^{\circ} 33^{\prime} 28.8^{\prime \prime} \mathrm{N}, 158^{\circ} 1^{\prime} 48^{\prime \prime} \mathrm{E}\right)$ is a Holocene caldera volcano, located at the northern end of the southern segment of the eastern volcanic belt of Kamchatka, $c$. $75 \mathrm{~km} \mathrm{SW}$ of PetropavlovskKamchatsky. It is one of the most active volcanoes in southern Kamchatka and currently contains an acidic crater lake which often displays persistent fumarolic activity with a steam plume up to several kilometres high on occasion (Kamchatka Volcanic Eruption Response Team, or KVERT). At the time of our campaign (September 2011), 


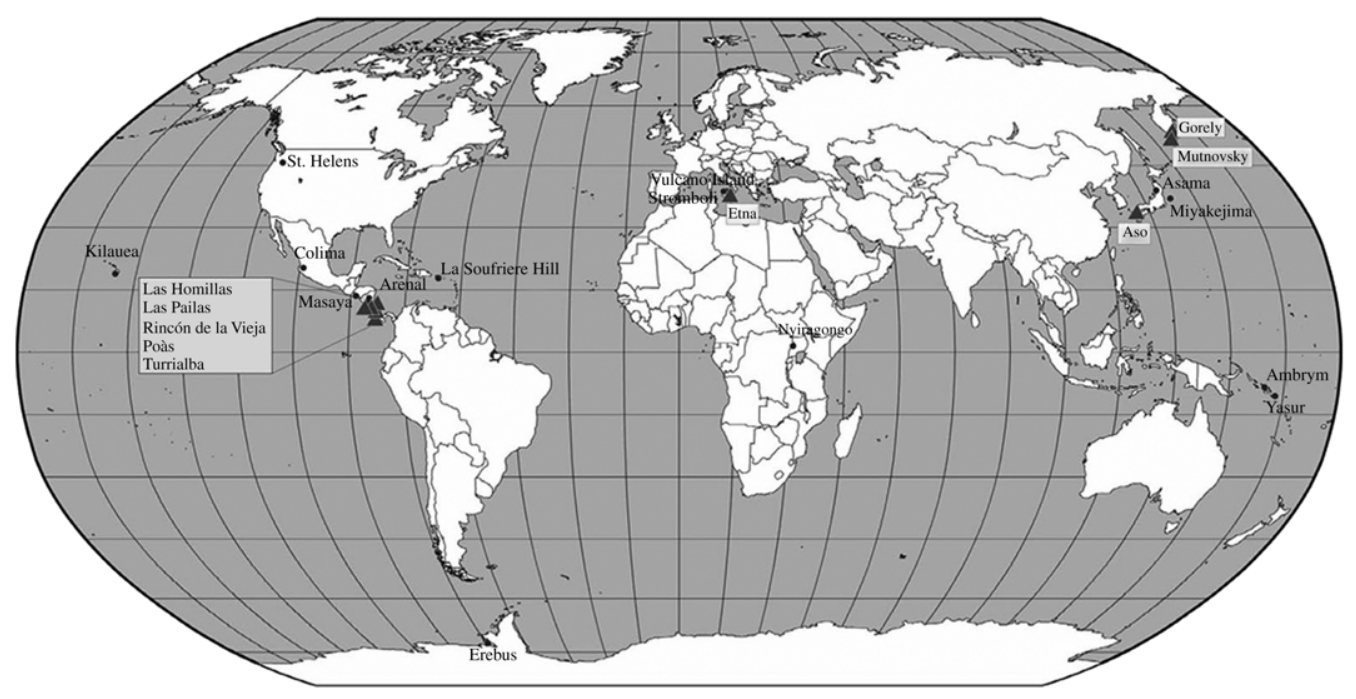

Fig. 1. Locations of the studied volcanoes and geothermal systems for which we reported data on $\mathrm{Hg}$ emission rate (black filled triangles), and for which literature data are summarized in Table 2 (black filled circles).

vigorous jet-like degassing was taking place from a hot open vent and hot fractures in the northern wall of the crater.

Mutnovsky volcano $\left(52^{\circ} 27^{\prime} 20.88^{\prime \prime} \mathrm{N}, 158^{\circ} 11^{\prime}\right.$ $\left.32.32^{\prime \prime}\right)$ is located in the southern part of the Eastern Volcanic Front of the Kamchatka Peninsula, and has an associated hydrothermal system with magmatic activity (Shishkina et al. 2010). There are three individual groups of fumaroles in the Mutnovsky crater which show stable activity for a long period of time: the 'Active Funnel' (temperatures exceed $600{ }^{\circ} \mathrm{C}$ ); the 'Bottom Field' (from 100 to $150{ }^{\circ} \mathrm{C}$ ); and the 'Upper Field' (up to $320^{\circ} \mathrm{C}$ ) (Taran et al. 1992). Our investigation focused on the degassing from the first two fumarolic groups.

Mt Etna is the largest volcano in Europe (NE coast of Sicily, south of Italy; $37^{\circ} 45^{\prime} 18^{\prime \prime} \mathrm{N}, 14^{\circ}$ $59^{\prime} 42^{\prime \prime} \mathrm{E}$ ) and one of the most active volcanoes in the world. Its present-day activity consists of persistent passive degassing of magmatic volatiles mostly from the four open vents on the volcano's summit (North East, Voragine, Bocca Nuova and South East) and diffuse soil emanations (Allard et al. 1991), occasionally interrupted by lava emissions associated with paroxysmal terminal to lateral eruptions (Madonia et al. 2013; Allard et al. 2006).

Poás $\left(10^{\circ} 12^{\prime} 0^{\prime \prime} \mathrm{N}, 84^{\circ} 12^{\prime} 0^{\prime \prime} \mathrm{W}\right)$ and Turrialba $\left(10^{\circ} 1^{\prime} 12.23^{\prime \prime} \mathrm{N}, 83^{\circ} 45^{\prime} 46.92^{\prime \prime} \mathrm{W}\right)$ volcanoes, Costa Rica, lie on the Central America Volcanic Front (Carr 1984; Carr et al. 2003). Turrialba is a stratovolcano that has seen increased fumarolic activity since 2002, with new fumarolic vents and fractures opening in and outside of the West Crater area in January 2010 and 2012, respectively. From 2007 onwards, after the hydrothermal stage which characterized the fumarolic discharge since at least the 1980s until fall 2001 (e.g. Cheminée et al. 1983; Vaselli et al. 2010), both the composition and high temperature (up to $800{ }^{\circ} \mathrm{C}$ ) of the fumaroles indicate that the gases are directly supplied from the magma chamber with only limited interaction with the hydrothermal system.

Poás is an andesitic-basaltic composite volcano about $50 \mathrm{~km}$ from the capital San José. Its upper part consists of three distinct eruptive centres roughly aligned NW-SE, including the Main Crater in the middle that hosts a hyper-acidic lake (Laguna Caliente, $\mathrm{pH}$ between 1.8 and c. 0 ) (Martínez et al. 2000; Melián et al. 2007; Martínez 2008). The activity of the lake (Laguna Caliente) is characterized by persistent fumarolic emissions and a long history of sporadic phreatic eruptions, especially since 2006 (Lopes 2005; Martínez 2008).

The Rincón de la Vieja volcanic complex $\left(10^{\circ}\right.$ $49^{\prime} 48^{\prime \prime} \mathrm{N}, 85^{\circ} 19^{\prime} 26^{\prime \prime} \mathrm{W}$ ) is a composite andesitic stratovolcano located in NW Costa Rica, c. $25 \mathrm{~km}$ from Liberia in the province of Guanacaste and $25 \mathrm{~km} \mathrm{NW}$ of the Miravalles volcano. It shows a wide range of fluid manifestations (a hyper-acidic crater lake, boiling- and mud-pools, thermal springs and associated gas discharges) (Tassi et al. 2005). The fluid vents located inside the Active Crater are likely to represent the most appropriate sampling sites for geochemical surveillance purposes; however, access is fairly difficult due to the steepness of the crater walls.

Las Hornillas and Las Pailas are two important geothermal systems which are part of the Miravalles 


\section{E. BAGNATO ET AL.}

and Rincón de la Vieja volcanic complexes, respectively (Guanacaste GeothermalProvince, CostaRica). Both show surface manifestations such as vapour discharges from fumaroles and steam-heated pools. Las Hornillas geothermal field is a high-temperature reservoir, located in the NW part of Costa Rica in the Guanacaste Volcanic Range, c. $150 \mathrm{~km}$ from the capital, San José. Temperatures generally range between 230 and $240{ }^{\circ} \mathrm{C}$ and gas discharges are dominated by $\mathrm{CO}_{2}$ with minor amounts of $\mathrm{H}_{2} \mathrm{~S}$ and $\mathrm{N}_{2}$ (Gherardi et al. 2002). The Las Pailas is a liquid-dominated two-phase reservoir with temperatures of $220-255^{\circ} \mathrm{C}$ (at a depth of about 600-700 m) (Castro 2002), located at the southern flank of the volcano Rincón de la Vieja, Guanacaste Volcanic Cordillera. The heat source is located in the west part of the area and fluid flows are from west to northeast. Fracture permeability enables fluid and heat transport in this reservoir.

\section{Major species in the plume}

Major volcanogenic species $\left(\mathrm{H}_{2} \mathrm{O}, \mathrm{CO}_{2}\right.$ and $\left.\mathrm{SO}_{2}\right)$ in volcanic plumes and fumaroles in tandem with $\mathrm{Hg}$ quantities have been measured at some locations (where logistics and weather conditions allowed) by using the MultiGAS analyser, a portable instrument previously described in Aiuppa et al. (2010, 2011). The plume gases are actively pumped into the sampler (using an air pump) at $1.2 \mathrm{~L} \mathrm{~min}^{-1}$ through a $1 \mu \mathrm{m}$ Teflon membrane particle filter and pumped through a $\mathrm{CO}_{2}$ gas detector (Licor LI-840 NDIR closed-path spectrometer; measurement range $0-$ 3000 ppm; accuracy $\pm 1.5 \%$ ) (see Shinohara et al. 2008 for details) and a suite of electrochemical sensors for $\mathrm{SO}_{2}$ (model $3 \mathrm{ST} / \mathrm{F}$ City Tech. Ltd., calibration range $0-200 \mathrm{ppm}), \mathrm{H}_{2} \mathrm{~S}$ (model EZ3H City Tech. Ltd., calibration range $0-50 \mathrm{ppm}$ ) and $\mathrm{H}_{2}$ (model EZT3HYT City Tech., calibration range 0-50 ppm) detection. A sensor for relative humidity and $T$ (model Galltec; $0-100 \%,-30$ to $70{ }^{\circ} \mathrm{C}$ ) was used in order to measure water content in the gaseous emissions. The sensors were housed in a weatherproof box mounted on a backpack frame and were calibrated, before and after fieldwork, with standard calibration gases (200 ppm $\mathrm{SO}_{2}, 50 \mathrm{ppm}$ $\mathrm{H}_{2} \mathrm{~S}, 20 \mathrm{ppm} \mathrm{H}_{2}$ and 3014 ppm $\mathrm{CO}_{2}$ ) mixed with ultrapure nitrogen to provide a range of desired concentrations (Aiuppa et al. 2011). The calibration gases also enabled cross sensitivity of the $\mathrm{H}_{2} \mathrm{~S}$ sensor to $\mathrm{SO}_{2}$ to be evaluated. Signals from sensors are simultaneously captured every $3 \mathrm{~s}$ by a datalogger board, which also enables data storage. The raw data are then processed by dedicated software (RatioCalc, by Tamburello, pers. comm. 2013) that allows a derivation of plume mass ratios of various compounds (e.g. $\mathrm{CO}_{2} / \mathrm{SO}_{2}, \mathrm{H}_{2} \mathrm{O} / \mathrm{CO}_{2}, \mathrm{H}_{2} \mathrm{O} / \mathrm{SO}_{2}$ ). Simultaneously, relative concentrations of $\mathrm{S}$ and
$\mathrm{Cl}$ were measured using the alkali-filter technique (Aiuppa et al. 2005; Shinohara \& Witter 2005), where air was pumped at a known flow rate (from 4 to $6 \mathrm{~L} \mathrm{~min}^{-1}$ ) through filter packs containing three cellulose impregnated filters stacked in series for c. 60-100 min. After exposure to the plume, $\mathrm{NaHCO}_{3}^{-}$impregnated filters were leached with bi-distilled water and $\mathrm{H}_{2} \mathrm{O}_{2}$ for 2 hours in order to extract $\mathrm{SO}_{4}{ }^{2-}$ and $\mathrm{Cl}^{-}$(Aiuppa et al. 2005). The leaching solution was then analysed for $\mathrm{SO}_{4}{ }^{2-}$ and $\mathrm{Cl}^{-}$by ion chromatography (IC) at DiSTeM, University of Palermo and INGV sez. Palermo (Italy). Blank filters and field blanks (i.e. filters from filter packs transported into the field and back in an identical manner to samples but not attached to a pump) were also analysed and found to be negligible compared to the measured values.

\section{Hg detection in volcanic emissions}

Gaseous mercury concentrations in volcanic plume have been measured mostly by using the conventional gold-trap technique (Ferrara et al. 2000; Aiuppa et al. 2007; Bagnato et al. 2007, 2009a, b; Witt et al. 2008a; Mather et al. 2012) and, more recently, by a portable mercury analyser LUMEXRA 915+ ${ }^{\circledR}$ (Sholupov et al. 2004; Aiuppa et al. 2007; Witt et al. 2008b; Bagnato et al. 2013). The Lumex-RA $915+{ }^{\circledR}$ analyser monitors gaseous elemental mercury (GEM) concentrations using differential atomic absorption spectrometry with correction for background absorption via the Zeeman Effect (Zeeman atomic absorption spectrometry using high-frequency modulation of light polarization or ZAAS-HFM; Sholupov et al. 2004). The $\mathrm{Hg}$ analysing system operates by pumping the air at $20 \mathrm{~L} \mathrm{~min}^{-1}$ through a c. $3 \mathrm{~cm}$ diameter inlet to the multi-path detection cell which has an effective path length of $10 \mathrm{~m}$. A zero correction resets the baseline every $5 \mathrm{~min}$ during sampling. The detection limit is c. $2 \mathrm{ng} \mathrm{m}^{-3}$, and the instrument has an accuracy of $20 \%$. Lumex ${ }^{\circledR}$ allows for measurements at the presence of high levels of humidity (not more than $95 \%$ ) and $\mathrm{H}_{2} \mathrm{~S}$ (not more than $100 \mathrm{mg} \mathrm{m}^{-3}$ ), unlike the conventional gold-trap technique which is instead strongly affected by inhibition of $\mathrm{Hg}$ adsorption at high $\mathrm{H}_{2} \mathrm{~S}$ levels (Schroeder et al. 1995). During the surveys, we measured an averaged relative humidity of $c .56 \%$ and $46 \%$ at Poàs and Turrialba volcanoes, respectively. The accuracy and precision of Lumex ${ }^{\circledR}$ has also been assessed through comparison with the traditional gold-trap/ cold vapour atomic fluorescence spectrometry (CVAFS) system used in this work and at remote sites elsewhere (Kim et al. 2006; Aiuppa et al. 2007; Witt et al. 2008b).

In this study, Lumex ${ }^{\circledR}$ has been employed in a stationary mode to collect gaseous elemental 
mercury (GEM) in the plumes of Turrialba (nearvent plume aging of a few seconds to a few minutes) and Poás volcanoes and by walking across the fumarolic areas of Las Pailas and Las Hornillas geothermal systems (at about $60 \mathrm{~cm}$ from the emitting vents). Gold-coated quartz sand traps (Au-traps; Brooks Rand Labs ${ }^{\circledR}$ ) were simultaneously used to collect total gaseous mercury (TGM) in the plumes (and/or fumaroles) of the studied volcanoes, where gas was pumped into the trap at a rate of $c .0 .5 \mathrm{~L} \mathrm{~min}^{-1}$ for sampling periods of c. $30 \mathrm{~min}$. An inline filter pack containing a filter impregnated with $1 \mathrm{M} \mathrm{NaHCO}_{3}$ was used in series with the gold traps to measure the corresponding $\mathrm{SO}_{2}$ concentration in the gas sampled (Aiuppa et al. 2007; Bagnato et al. 2007, 2011), and a $45 \mu \mathrm{m}$ Teflon pre-filter has been located on the head of the gold-trap assembly to filter atmospheric air. On a few occasions a second gold trap was connected in series in order to monitor potential GEM breakthrough on the first trap, but this proved negligible. After sampling, the traps were sealed and analysed at the Midi-Pyrenees Observatory (Toulouse, France) by using dual-stage gold-trap amalgamation with atomic fluorescence detection (AFS, Brook Rand Model III) which employs highpurity argon as a carrier gas. The sampling train consists of the sampling gold trap followed by a new soda lime trap (Tekran Inc.), an analytical goldcoated sand trap (Brooks Rand) and the AFS detector. The soda lime trap was used to neutralize water vapour, residual acid gases and other impurities that may be co-collected on sampling traps under volcanic conditions. The AFS was calibrated using 40-200 uL Hg vapour injections from a thermostated liquid/vapour $\mathrm{Hg}$ reservoir. Calibration was repeated every three samples and showed a drift of the signal of $<10 \%$. More details on the operating conditions are given in Sonke et al. (2008).

Some studies address the question of whether the collection of gaseous $\mathrm{Hg}$ using a gold trap quantifies TGM (i.e. GEM plus RGM) or GEM; see Gustin et al. (1999) as an example. For the sake of simplicity, GEM and $\mathrm{Hg}$ are used without distinction in this article unless otherwise specified since in volcanic emissions GEM is the dominant form ( $\geq 90 \%$; Bagnato et al. 2007; Zambardi et al. 2009; von Glasgow 2010; Martin et al. 2011).

\section{Volcanic Hg flux estimate}

Estimating the emission flux of $\mathrm{Hg}$ from volcanoes (plume and fumaroles) has generally taken the approach of scaling relationships between averaged $\mathrm{Hg} / \mathrm{SO}_{2}$ ratios in gas emissions and $\mathrm{SO}_{2}$ fluxes (Varekamp \& Buseck 1986; Pyle \& Mather 2003; Aiuppa et al. 2007; Bagnato et al. 2007; Witt et al. 2008a, b; Bagnato et al. 2011) since volcanic
$\mathrm{SO}_{2}$ is well monitored and there is a degree of consensus over the global volcanic $\mathrm{SO}_{2}$ flux (Graf et al. 1997; Andres \& Kasgnoc 1998; Halmer et al. 2002; Schmidt et al. 2012). If the ratio $\mathrm{Hg} /$ $\mathrm{SO}_{2}$ in volcanic plumes can be reliably constrained, the emission flux of $\mathrm{Hg}$ can be estimated. The former ratio is usually determined by connecting alkali-impregnated filters (to trap plume $\mathrm{SO}_{2}$; accuracy $\pm 10 \%$ at $1 \mathrm{~s}$; Aiuppa et al. 2004, 2005) in series or in parallel with the gold trap. An additional effective method we used to assess the averaged $\mathrm{Hg} / \mathrm{SO}_{2}$ ratio in volcanic emissions is to combine the Lumex analyser in parallel with the MultiGAS to obtain real-time measurements of $\mathrm{Hg}$ and major volatiles in the volcanic fumes (Aiuppa et al. 2007; Witt et al. 2008a, b; Bagnato et al. 2013). In this study, data on sulphur dioxide flux in the volcanic plumes have been measured directly and acquired from literature reports. At Mt Etna, Gorely and Mutnovsky volcanoes a dual-UV camera set-up was used to obtain time series of the $\mathrm{SO}_{2}$ flux at a resolution of $0.33 \mathrm{~Hz}$ (Kantzas et al. 2010; Tamburello et al. 2011; Aiuppa et al. 2012). This technique allows the whole plume to be captured in a single image, allowing the possibility of exploring spatial variations in $\mathrm{SO}_{2}$ emissions over a timescale of c. $1 \mathrm{~s}$ (Mori \& Burton 2006; Bluth et al. 2007). For the other reported volcanoes, $\mathrm{SO}_{2}$ flux estimates have been obtained by traversing beneath the plume with an ultraviolet Ocean Optics USB2000 spectrometer coupled to a vertically pointing telescope, or by downloading data from an installed permanent station close to the volcano. Evaluation methods of the acquired spectra are described in McGonigle et al. (2002) and Galle et al. (2003). All the $\mathrm{SO}_{2}$ fluxes used in our calculations correspond to the period of our fieldwork. In these calculations, we assume that GEM and $\mathrm{SO}_{2}$ are the main forms of $\mathrm{Hg}$ (Bagnato et al. 2007, 2011) and $\mathrm{S}$ in the plumes, respectively. Under certain circumstances however, such as those encountered in the geothermal fields (i.e. the $\mathrm{S}$ fluxes are very low), the $\mathrm{Hg}$ / $\mathrm{SO}_{2}$ approach for estimating $\mathrm{Hg}$ flux is not readily applicable since there is no reliable method for measuring the flux of the dominant form of sulphur in these systems. In those areas, we used an alternative method to estimate $\mathrm{Hg}$ flux by combining the kriging contouring technique with the plume speed information (Bagnato et al. 2013).

\section{Results}

\section{Mercury and major species in volcanic emissions}

The simultaneous acquisition of $\mathrm{CO}_{2}, \mathrm{H}_{2} \mathrm{~S}, \mathrm{SO}_{2}$ and $\mathrm{H}_{2} \mathrm{O}$ by the MultiGAS (Aiuppa et al. 2005, 2007, 


\section{E. BAGNATO ET AL.}

2011) combined with Lumex $\mathrm{Hg}$ analyser allowed us to characterize the abundance of major species in air-diluted volcanic emissions, and therefore examine the relationship between atmospheric $\mathrm{Hg}$ concentrations and volcanogenic volatiles (see Tables $1 \& 2$ ). More specifically, data from the permanent MultiGAS station installed on the western rim of Turrialba volcano's West Crater showed $\mathrm{CO}_{2} / \mathrm{SO}_{2}$ molar ratio time series almost constant over a period of two days, ranging from 1.15 to 2.55 and averaging 2.2. Instead, the $\mathrm{H}_{2} \mathrm{O} / \mathrm{CO}_{2}$ molar ratio varies over a wide range from 32 to 230 (mean 109) due to water condensation that removes water from the gas of the low-temperature sources (see Table 1). Here, simultaneous collection of gases by Lumex and gold-trap technique yielded $\mathrm{Hg}$ concentrations of 99 and $81 \mathrm{ng} \mathrm{m}^{-3}$, respectively (Table 2 ), which are comparable to those obtained during previous fieldwork performed in 2010 (averaged GEM c. $115 \mathrm{ng} \mathrm{m}^{-3}$, Table 2; Bagnato et al. unpublished data). Higher averaged GEM values were measured in the volcanic plumes of Mt Etna's craters (Bocca Nuova and North East craters; 125 and $100 \mathrm{ng} \mathrm{Hg} \mathrm{m}^{-3}$, respectively), where the continuous measurements by MultiGAS gave $\mathrm{H}_{2} \mathrm{O} / \mathrm{CO}_{2}$ and $\mathrm{H}_{2} \mathrm{O} / \mathrm{SO}_{2}$ values of $c .93$ and 46.5, respectively (Tables 1 and 2). We found that $\mathrm{Hg}$ data from the North East crater $(99 \mathrm{ng}$ $\mathrm{Hg} \mathrm{m}^{-3}$; this work) is comparable to the lower value reported by Bagnato et al. (2007) (range 114-328 $\mathrm{ng} \mathrm{Hg} \mathrm{m}^{-3}$; Table 2). A very recent MultiGAS survey on Gorely's volcanic plume (Aiuppa et al. 2012) reports $\mathrm{H}_{2} \mathrm{O} / \mathrm{SO}_{2}=43 \pm 13$, $\mathrm{CO}_{2} / \mathrm{SO}_{2}=1.2 \pm 0.1$ and $\mathrm{H}_{2} / \mathrm{SO}_{2}=0.11 \pm 0.02$ as a representative mean end-member for arc magmatism in the NW Pacific region (Table 1). These data have been acquired simultaneously to our $\mathrm{Hg}$ measurements inside the dilute plume of Gorely (at c. $300 \mathrm{~m}$ downwind from the source), where we found the lowest GEM concentrations (c. $4 \mathrm{ng} \mathrm{m}^{-3}$; Table 2) of those reported in this study.

The four transects performed with the portable MultiGAS on the rim of the dome close to the acidic lake at Poás volcano did not show relevant variability of the chemical composition; the $\mathrm{CO}_{2}$ / $\mathrm{SO}_{2}$ molar ratio ranged between 0.23 and 0.45 (mean 0.4; Table 1), suggesting a strong homogeneity of the fumarolic field. The $\mathrm{H}_{2} \mathrm{O} / \mathrm{CO}_{2}$ ratio is affected by condensation of water and is therefore more variable (170-215; mean 183; Table 1$)$. The $\mathrm{SO}_{2} / \mathrm{H}_{2} \mathrm{~S}$ ratio fell within the range 2-6.8, supporting a more extensive re-equilibration of the volcanic gas within the more reducing and colder hydrothermal system. A further short survey was carried out around the edge of the acid lake of Poás volcano, aimed at detecting the chemistry of the steam released by the lake. The results show higher values of both $\mathrm{CO}_{2} / \mathrm{SO}_{2}$ and $\mathrm{H}_{2} \mathrm{O} / \mathrm{CO}_{2}, 1.2$ and 344 respectively, reflecting the contribution of water evaporation and $\mathrm{SO}_{2}$ scrubbing processes (Symonds et al. 2001). Simultaneous Hg measurements by both gold traps and Lumex system in the fumarolic emissions collected on the top of the dome (hundreds of metres from the emissions) gave very low concentrations $\left(6-7.4 \mathrm{ng} \mathrm{m}^{-3}\right.$; Table 2). In general, given the uncertainties associated with gold-trap techniques, our data exhibit a good agreement by comparing Lumex ${ }^{\circledR}$ and gold-trap results (see Table 2), as also reported elsewhere by other authors (Kim et al. 2006; Aiuppa et al. 2007).

A first assessment of the chemical composition of gases released by the fumarolic field inside and near the bottom of Rincón de la Vieja's main crater has also been accomplished. Despite the great distance from which the gas was detected by the MultiGAS (hundreds of metres from the fumaroles), the concentrations of volcanic $\mathrm{SO}_{2}$ and $\mathrm{CO}_{2}$ were high enough (c. 1 and $10 \mathrm{ppm}$, respectively) to calculate molar ratios. In fact, the $0.8 \mathrm{~km}^{2}$ wide hyper-acid lake at the bottom of the crater exerts a strong gas scrubbing on the volcanic gas emissions, as demonstrated by the high $\mathrm{CO}_{2} / \mathrm{SO}_{2}$ molar ratios in the range 15-69, averaging 27 (see Table 1). The measured $\mathrm{H}_{2} \mathrm{O} / \mathrm{CO}_{2}$ ratios are variable (range 84-354) but still comparable to the other volcanoes. As at Poàs, we detected very small $\mathrm{Hg}$ concentrations in the emissions from Rincón de la Vieja volcano (in the range $4-5 \mathrm{ng} \mathrm{m}^{-3}$; Table 2). The quite low $\mathrm{Hg}$ concentrations found in the fumes of these latter two volcanoes mainly reflect the long distance from which the gas was detected (hundreds of metres from the fumarolic emissions), and probably the gas scrubbing on gaseous emissions exerted by the acid volcanic lakes hosted inside (Symonds et al. 2001). However, more research is needed to improve knowledge of the implications of magmatic gas scrubbing on $\mathrm{Hg}$ distribution in volcanic emanations.

The fumarolic gas of Aso volcano is a mixture of the original magmatic gas and hydrothermal fluids (Shinohara et al. 2010, 2013). The authors suggest that gases deriving from the lake and fumarolic emissions have distinct compositions, with higher $\mathrm{CO}_{2} / \mathrm{SO}_{2}$ and $\mathrm{HCl} / \mathrm{SO}_{2}$ (3.1 and 0.1 , respectively) and lower $\mathrm{SO}_{2} / \mathrm{H}_{2} \mathrm{~S}$ (19.2) ratios in fumaroles than the lake gases (1.6, 420 and 0.01 , respectively), but they have similar $\mathrm{H}_{2} / \mathrm{CO}_{2}$ ratios $(0.06$ and 0.03 , respectively) (Table 1 ). Here we attempted separate quantification of $\mathrm{Hg}$ in the gases emitted from the Yudamari crater lake (lake gas) and the fumarolic area at the southern wall (fumarolic gas) by using the gold-trap method at two distinct sampling sites. Since the gas source is not a single vent for both the lake gases and the fumarolic gases, 
Table 1. Molar ratios measured in the plume of the investigated volcanoes and in atmospheric emissions of geothermal systems

\begin{tabular}{lrrl}
\hline Volcano & $\begin{array}{r}\mathrm{H}_{2} \mathrm{O} / \\
\mathrm{CO}_{2}\end{array}$ & $\begin{array}{r}\mathrm{H}_{2} \mathrm{O} / \\
\mathrm{SO}_{2}\end{array}$ & $\begin{array}{c}\mathrm{CO}_{2} / \\
\mathrm{SO}_{2}\end{array}$ \\
\hline Turrialba & 109 & 240 & 2.2 \\
Poás & 183 & 73 & 0.4 \\
Rincón de la Vieja & 201 & 5424 & 27 \\
Aso fumarole* & 17 & 52 & 0.0012 \\
Aso lake gas & 58 & 94 & 0.0002 \\
Gorely & 32 & 43 & 1.3 \\
Mutnovsky AF & 23 & 46 & 0.001 \\
Mutnovsky BF & 83 & 288 & 0.00004 \\
Etna NEC & 93 & 46 & 0.5 \\
Etna BN & 21 & 126 & 6 \\
Geothermal fields & & & \\
Las Pailas & 378 & 15031 & 41 \\
Las Hornillas & 29 & 3220 & 113 \\
\hline
\end{tabular}

*Shinohara et al. (2010)

†Shinohara et al. (2013)

${ }^{\ddagger}$ Aiuppa et al. (2012)

there can be some heterogeneity in composition as well as composition fluctuation. It is therefore quite difficult to estimate the real error in composition determination. Mercury measurements at Aso volcano gave values of $c .119$ and $8 \mathrm{ng} \mathrm{Hg}$ $\mathrm{m}^{-3}$ in the fumaroles and fumes generated by the crater lake evasion, respectively (Table 2). The mismatch exhibited by these data mainly reflects the weak gaseous emission from the surface of Yudamari crater lake during the survey compared to the strong degassing exhibited by the fumaroles sampled along the wall of the crater.

Finally, MultiGAS survey performed at the Bottom Field and the Active Crater of the Mutnovsky volcano yielded $\mathrm{H}_{2} \mathrm{O} / \mathrm{S}_{\text {tot }}$ molar ratios in the range $c$. 46.4-288.3, while the measured $\mathrm{H}_{2} \mathrm{O}$ / $\mathrm{CO}_{2}$ and $\mathrm{CO}_{2} / \mathrm{S}_{\text {tot }}$ ratios were 23.4 and 2 for the former and 83 and 3.4 for the fumaroles of the Bottom Field (Table 1). Simultaneously, we also measured $c .40$ and $8 \mathrm{ng} \mathrm{Hg} \mathrm{m}^{-3}$ in the atmospheric emissions from the Active Crater and the Bottom Field, respectively (Table 2).

In general, our results are higher than the background atmospheric $\mathrm{Hg}$ values generally found in the unpolluted areas of the Northern Hemisphere (range 1.5-1.7 $\mathrm{ng} \mathrm{m}^{-3}$; Lindberg et al. 2007; Sprovieri et al. 2010), as well in the urban sites (range 2.5-9.8 $\mathrm{ng} \mathrm{m}^{-3}$; Liu et al. 2002; Rutter et al. 2008, 2009; Kim et al. 2011). The large variability of GEM concentrations $\left(4-125 \mathrm{ng} \mathrm{m}^{-3}\right)$ we measured in the gaseous emissions of the investigated volcanoes strongly reflects the dynamic nature of the plume, where the abundances of volatiles are determined by variations in $\mathrm{Hg}$ emission fluxes from magma and dilution with background air. Overall, our data support the relevance of persistent volcanic activity from open-conduit degassing as a significant source of $\mathrm{Hg}$ for the atmosphere (see Table 2), and fall within the range proposed by many authors worldwide (Witt et al. 2008a, $b$; Bagnato et al. 2011; Mather et al. 2012; Table 2).

\section{Hg emissions from geothermal fields}

There are relatively few published datasets of $\mathrm{Hg}$ concentrations measured at or near geothermal features even if many areas characterized by geothermal activity have long been associated with elevated levels of $\mathrm{Hg}$ in soils and air (Varekamp \& Buseck 1981, 1986; Cox 1983; Siegel \& Siegel 1984). Previous studies by Robertson et al. (1977) and Christenson and Mroczek (2003) showed that essentially all the $\mathrm{Hg}$ in geothermal steam and gases is in the gaseous elemental form (GEM). A Lumex ${ }^{\circledR} /$ MultiGAS GPS-synchronized survey was carried out at Las Hornillas and Las Pailas geothermal fields (Costa Rica) with the aim of quantifying volatile species in the fumarolic emissions distributed in these areas. At each fumarole, measurements were performed by placing the inlet of the instruments close (within a few centimetres) to the emitting vent to reduce mixing with air. The combined Lumex ${ }^{\circledR} /$ MultiGAS technique allowed a large number of simultaneous GEM and $\mathrm{SO}_{2}$ measurements to be made over short (half an hour) observation periods, and the time variability of the $\mathrm{GEM} / \mathrm{SO}_{2}$ ratio to be evaluated real-time. The MultiGAS survey revealed a spatial variability in terms of gas compositions and emission rate for both investigated geothermal areas (Table 1; Figs $2 \& 3)$. We estimated an averaged $\mathrm{CO}_{2} / \mathrm{H}_{2} \mathrm{~S}$ ratio ranging between 53 and 179 (with the higher values measured at the northern part of the field) and between 16.3 and 73 at Las Hornillas and Las Pailas, respectively. At Las Hornillas we also estimated an averaged $\mathrm{H}_{2} \mathrm{O} / \mathrm{CO}_{2}$ ratio ranging from 23 to 53, while at Las Pailas $\mathrm{H}_{2} \mathrm{O} / \mathrm{H}_{2} \mathrm{~S}$ and $\mathrm{H}_{2} \mathrm{O} / \mathrm{CO}_{2}$ ratios were estimated to vary from 8835 to 29994 and from c. 230 to 542, respectively (Table 1). By walking around the fumarolic emissions, we estimated GEM concentrations of 140-530 $\mathrm{ng} \mathrm{m}^{-3}$ (averaged $260 \mathrm{ng} \mathrm{m}^{-3}$ ) and c. $145-1329 \mathrm{ng} \mathrm{m}^{-3}$ (averaged $822 \mathrm{ng} \mathrm{m}^{-3}$ ) for Las Pailas and Las Hornillas emissions, respectively (Table 2; Figs 2 \& 3). Measurements showed that both systems are releasing $\mathrm{Hg}$ at elevated levels well above those measured in the atmosphere outside the geothermal areas (c. 3.6 and $3.2 \mathrm{ng} \mathrm{m}^{-3}$ for Las Pailas and Las Hornillas, respectively). Measurements performed by a FLIR SC660 infrared camera (located near the main vents) showed a very homogeneous distribution of 
Table 2. Volcanic mean GEM concentrations (range; SD and number of measurements), mean GEM/SO $\mathrm{O}_{2}$ mass ratios and Hg fluxes for the volcanic systems used in this study

\begin{tabular}{|c|c|c|c|c|c|c|c|c|c|c|}
\hline Volcano & Location & Date & Volcanism & $\begin{array}{l}\text { Emission } \\
\text { type }\end{array}$ & $\begin{array}{l}\text { GEM }\left(\mathrm{ng} \mathrm{m}^{-3}\right. \\
(\text { range; SD; } n))\end{array}$ & Method & $\mathrm{GEM} / \mathrm{SO}_{2}$ & $\underset{\left(\mathrm{t} \mathrm{a}^{-1}\right)}{\Phi \mathrm{SO}_{2}}$ & $\underset{\left(\mathrm{t} \mathrm{a}^{-1}\right)}{\Phi \mathrm{Hg}}$ & References \\
\hline Gorely & Kamchatka & $06 / 09 / 2011$ & Arc & Plume & $4(I)$ & Au-trap/AFS & $3.3 \times 10^{-6}$ & $802^{1}$ & 0.95 & This study \\
\hline Mutnovsly AF & Kamchatka & $05 / 09 / 2011$ & Arc & Fumaroles & $8(1)$ & Au-trap/AFS & $1.9 \times 10^{-7}$ & $150^{2}$ & 0.01 & This study \\
\hline Mutnovsly BF(both plumes) & Kamchatka & $05 / 09 / 2011$ & Arc & Fumaroles & $40(1)$ & Au-trap/AFS & $1.4 \times 10^{-5}$ & $150^{2}$ & $0.7(0.71)$ & This study \\
\hline Aso fumarole & Japan & 2010 & Arc & Fumaroles & $119(1)$ & Au-trap/AFS & $5.2 \times 10^{-7}$ & $500^{3}$ & 0.09 & This study \\
\hline Aso crater lake (both plumes) & Japan & 2010 & Arc & Lake fumes & $8(1)$ & Au-trap/AFS & $1.3 \times 10^{-6}$ & $500^{3}$ & $0.24(0.33)$ & This study \\
\hline Etna BN & Italy & $24 / 06 / 2011$ & Non-arc & Plume & $125(1)$ & Au-trap/AFS & $7.1 \times 10^{-6}$ & $1130^{4}$ & 2.92 & This study \\
\hline Etna NEC (both plumes) & Italy & $24 / 06 / 2011$ & Non-arc & Plume & $99(1)$ & Au-trap/AFS & $3.4 \times 10^{-6}$ & $1000^{4}$ & $1.24(4.16)$ & This study \\
\hline Poás & Costa Rica & $16-18 / 04 / 2013$ & Arc & Fumaroles & $7.4(5-10)$ & Lumex & $\begin{array}{l}4.9 \times 10^{-8} \\
\quad\left(2.5-3.6 \times 10^{-8}\right)\end{array}$ & $120^{5}$ & 0.002 & This study \\
\hline Poás & Costa Rica & $16-18 / 04 / 2013$ & Arc & Fumaroles & $6(4-7 ; 1.2 ; 5)$ & Au-trap/AFS & $\begin{array}{l}3.7 \times 10^{-8} \\
\left(2.1-5.4 \times 10^{-8}\right)\end{array}$ & $120^{5}$ & 0.0016 & This study \\
\hline Turrialba & Costa Rica & $07 / 03 / 2011$ & Arc & Plume & $115(1)$ & Au-trap/AFS & $3.9 \times 10^{-6}$ & $1000^{6}$ & 1.45 & This study \\
\hline Turrialba & Costa Rica & $02-04 / 04 / 2013$ & Arc & Plume & $100(68-174)$ & Lumex & $\begin{array}{l}5.6 \times 10^{-6} \\
\quad\left(3-9.8 \times 10^{-6}\right)\end{array}$ & $671^{7}$ & 1.4 & This study \\
\hline Turrialba & Costa Rica & $02-04 / 04 / 2013$ & Arc & Plume & $81(76-85 ; 4 ; 3)$ & Au-trap/AFS & $\begin{array}{l}8.1 \times 10^{-6} \\
\quad\left(7.6-8.2 \times 10^{-6}\right)\end{array}$ & $671^{7}$ & 1.9 & This study \\
\hline Rincón de la Vieja & Costa Rica & $07 / 04 / 2013$ & Arc & Fumaroles & $5(4-5 ; 0.6 ; 2)$ & Au-trap/AFS & $\begin{array}{l}3.5 \times 10^{-6} \\
\quad\left(4.3-2.7 \times 10^{-6}\right)\end{array}$ & n.d. & n.d. & This study \\
\hline Las Pailas & Costa Rica & $08 / 04 / 2013$ & Arc & Geothermal & $260(140-530)$ & Lumex & $1.68 \times 10^{-5}$ & n.d. & $0.0008-0.002$ & This study \\
\hline Las Hornillas & Costa Rica & $09 / 04 / 2013$ & Arc & Geothermal & $822(145-1329)$ & Lumex & $4.01 \times 10^{-6}$ & n.d. & $0.004-0.01$ & This study \\
\hline Nyiragongo & Africa & $19-23 / 06 / 2010$ & Non-arc & Plume & 373 & Au-trap/CVAFS & $5.5 \times 10^{-6}$ & 2180 & 4.4 & Bagnato et al. (2011) \\
\hline Yasur & Vanuatu & $21 / 10 / 2010$ & Arc & Plume & 84 & Au-trap/CVAFS & $1.7 \times 10^{-5}$ & 940 & 6 & Bagnato et al. (2011) \\
\hline Ambrym & Vanuatu & $21 / 10 / 2010$ & Arc & Plume & 68 & Au-trap/CVAFS & $6.4 \times 10^{-6}$ & 7600 & 18 & Bagnato et al. (2011) \\
\hline Stromboli & Italy & $24 / 07 / 2008$ & Arc & Plume & 28 & Au-trap/CVAFS & $4.7 \times 10^{-6}$ & 120 & 0.2 & Bagnato et al. (2011) \\
\hline Miyakejima & Japan & $02-12 / 09 / 2006$ & Arc & Plume & 95 & Au-trap/CVAFS & $9 \times 10^{-6}$ & 2000 & 6.6 & Bagnato et al. (2011) \\
\hline Asama & Japan & $25-29 / 09 / 2008$ & Arc & Plume & 41 & Au-trap/CVAFS & $5.5 \times 10^{-6}$ & 1850 & 3.7 & Bagnato et al. (2011) \\
\hline La Soufriere Hill & $\begin{array}{l}\text { Less } \\
\text { Antilles }\end{array}$ & $01 / 07 / 2008$ & Arc & Plume & 18 & Au-trap/CVAFS & $1.2 \times 10^{-5}$ & 400 & 1.8 & Bagnato et al. (2011) \\
\hline Kilauea & Hawaii & 2008 & Arc & Plume & 35 & Au-trap/CVAFS & $1.6 \times 10^{-6}$ & 700 & 0.2 & Mather et al. (2012) \\
\hline Masaya & Nicaragua & $\begin{array}{r}24 / 02-04 / \\
03 / 2006\end{array}$ & Arc & Plume & 163.5 & Au-trap/CVAFS & $2 \times 10^{-5}$ & 800 & 7.2 & Witt et al. $(2008 a, b)$ \\
\hline \multirow{2}{*}{\multicolumn{8}{|c|}{$\begin{array}{l}\text { Cumulative flux from open-conduit volcanoes } \\
\text { Global volcanism emissions }\end{array}$}} & 16590 & 56 & This study \\
\hline & & & & & & & & $\begin{array}{l}18630- \\
38904^{8}\end{array}$ & $76 \pm 30$ & This study \\
\hline
\end{tabular}

Literature Hg flux with relevant data sources and sampling/analythical methods are also reported: ${ }^{1}$ Aiuppa et al. (2012), ${ }^{2}$ G. Tamburello pers. comm., 2011; ${ }^{3}$ Shinohara et al. (2010); ${ }^{4}$ G. Tamburello pers. comm., 2013; ${ }^{5}$ M. DeMoor pers. comm., 2013; ${ }^{6}$ Campion et al. (2012); ${ }^{7}$ G. Avard pers. comm., 2013; ${ }^{8}$ Graf et al. (1997). 


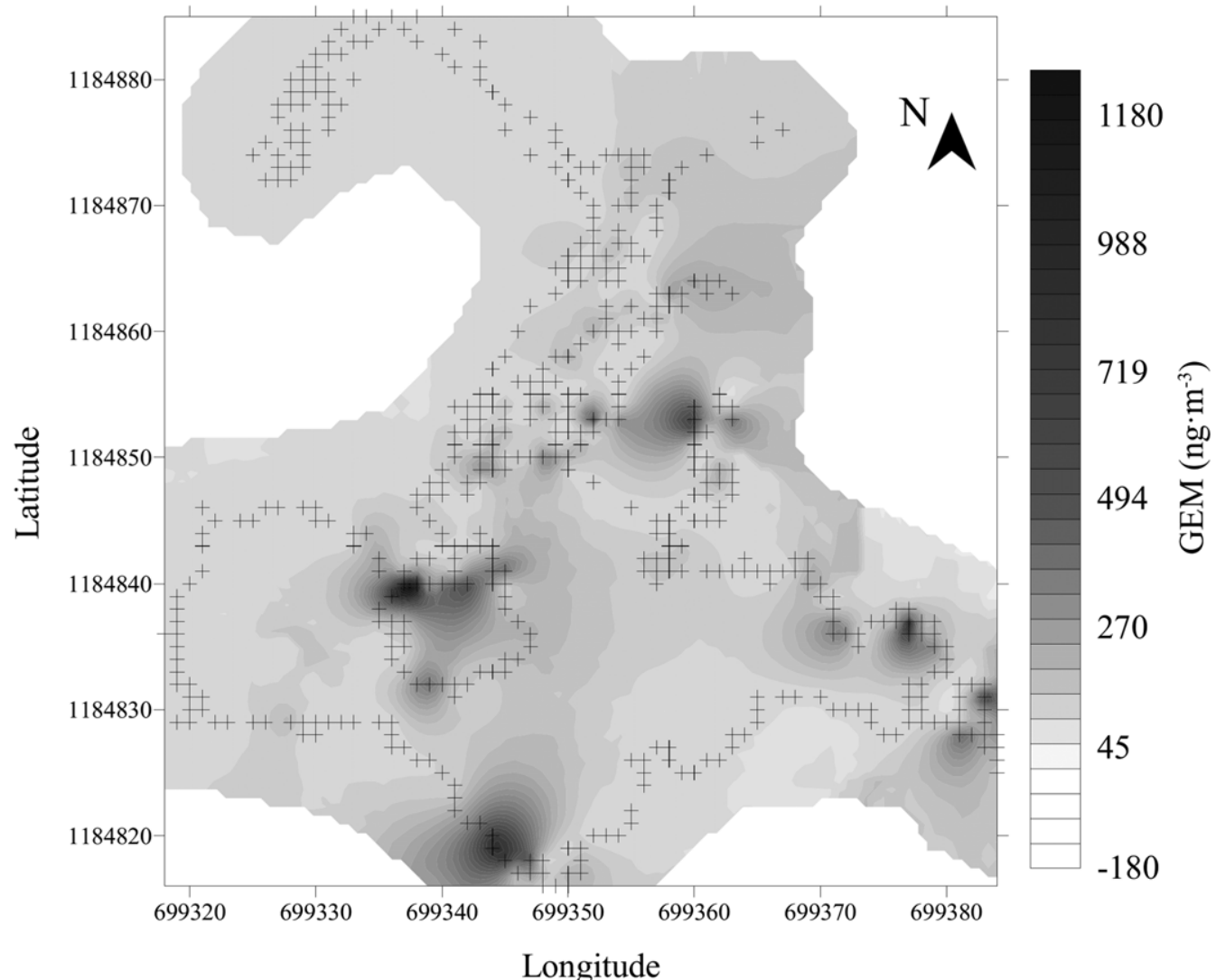

Fig. 2. Mercury distribution $\left(\mathrm{ng} \mathrm{m}^{-3}\right)$ in gaseous emissions at Las Hornillas geothermal field, Miravalles volcano, Costa Rica. The black crosses indicate the walking track across the fumarolic emission sites with the Lumex/MultiGAS synchronized survey. Coordinates are reported in UTM (Zone 16P).

gas temperatures at the emitting vents, generally close to the boiling point of water and ranging from 95 to $98^{\circ} \mathrm{C}$ in both geothermal areas. Acquisition by the Lumex ${ }^{\circledR}$ system allowed us to detect pulsed sequences of GEM increases in the atmospheric plumes of the fumaroles of both geothermal systems (Fig. 4a, b). These GEM pulses were closely matched by parallel increases in $\mathrm{CO}_{2}$ as illustrated in Figure 4a, b, supporting both a volcanic origin for the measured GEM concentrations and the role of early $\mathrm{CO}_{2}$ escape from magmas as a carrier gas for $\mathrm{Hg}$ (Varekamp \& Buseck 1981, 1986; Bagnato et al. 2013). At Las Pailas we estimated mean $\mathrm{GEM} / \mathrm{CO}_{2}$ mass ratios ranging from $1.4 \times 10^{-9}$ to $1.7 \times 10^{-8}$, comparable with those measured in the gaseous manifestations at Las Hornillas field (from $3.5 \times 10^{-9}$ to $1 \times 10^{-7}$ ). In general, our estimated $\mathrm{GEM} / \mathrm{CO}_{2}$ values are similar to those obtained in other low-temperature volcanic-hydrothermal systems such as Tatun volcanic field $\left(\mathrm{GEM} / \mathrm{CO}_{2}\right.$ from $4 \times 10^{-8}$ to $40 \times 10^{-8}$; Witt et al. 2008a) and the low-T $\left(85^{\circ}-150{ }^{\circ} \mathrm{C}\right) \quad \mathrm{CO}_{2}$-rich fumaroles of Masaya volcano $\left(\mathrm{GEM} / \mathrm{CO}_{2}\right.$ from $0.1 \times 10^{-8}$ to $1.9 \times$ $10^{-8}$; Witt et al. 2008b). Measurements at the higher-temperature $\left(250{ }^{\circ} \mathrm{C}\right)$ fumaroles of $\mathrm{La}$ Fossa Crater, Vulcano island indicated GEM $/ \mathrm{CO}_{2}$ mass ratio of $6.0 \times 10^{-8}$ (Aiuppa et al. 2007). Our data are also close to the values reported by Engle et al. (2006) for the fumaroles at Yellowstone Caldera, a hydrothermal system with temperatures ranging from 85 to $95{ }^{\circ} \mathrm{C}$ and in the presence of $\mathrm{H}_{2} \mathrm{~S}\left(1.6 \times 10^{-9}\right.$ to $2.6 \times 10^{-9}$; Engle et al. 2006). The GEM concentrations derived from the real-time measurements at Las Pailas geothermal field also correlate well with the real-time $\mathrm{H}_{2} \mathrm{O}$ concentrations at all the active vents (Fig. 4b) with estimated mean $\mathrm{GEM} / \mathrm{H}_{2} \mathrm{O}$ mass ratios ranging from $4.3 \times 10^{-11}$ to $3.6 \times 10^{-10}$. These results provide new important information, improving the 


\section{E. BAGNATO ET AL.}
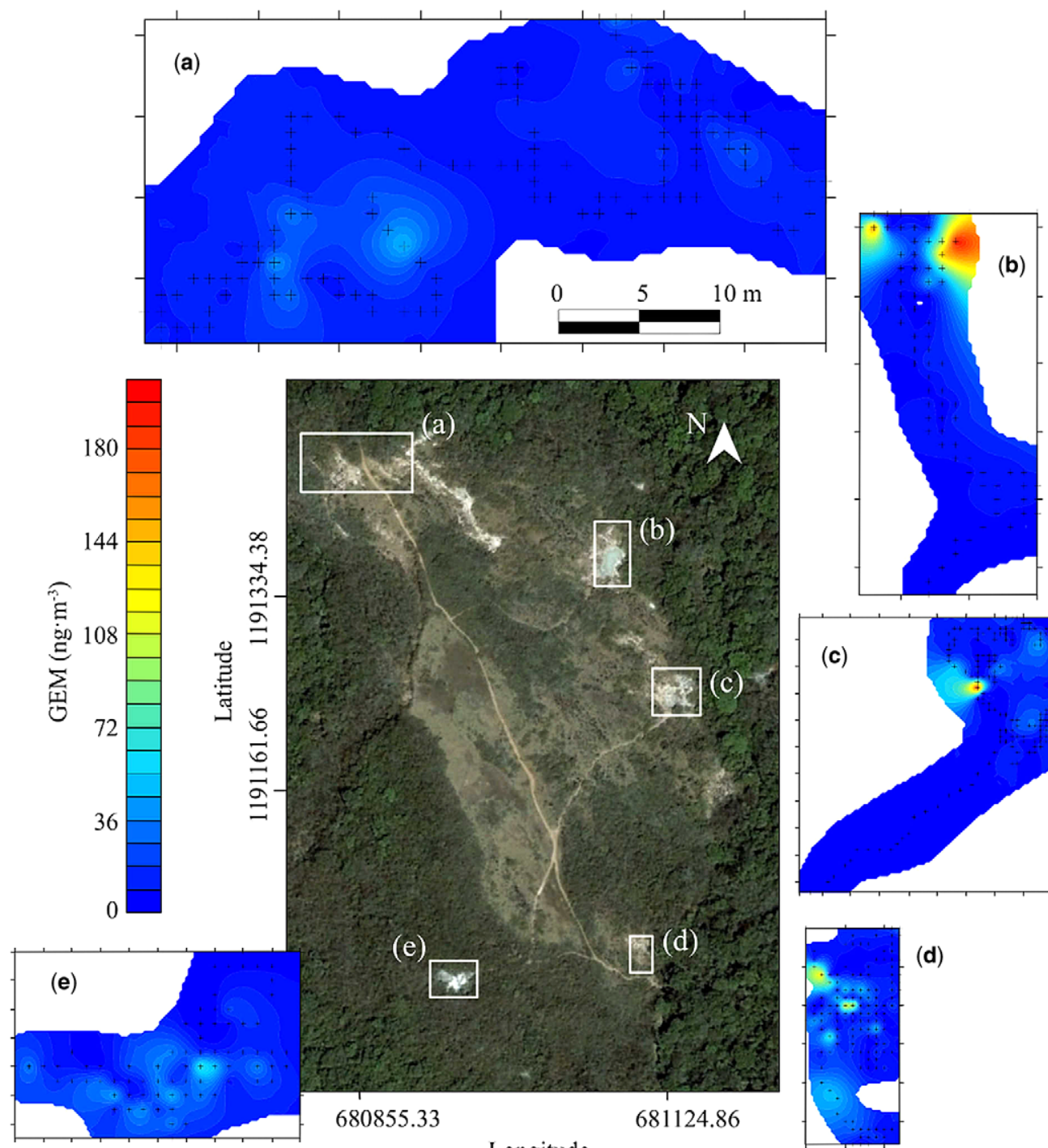

Longitude

Fig. 3. Mercury distribution $\left(\mathrm{ng} \mathrm{m}^{-3}\right)$ in gaseous emissions at Las Pailas geothermal field, Rincón de la Vieja volcano, Costa Rica by the Lumex/MultiGAS acquisition technique. Here the surveyed areas are reported in five separated sectors (a-e) due to the extended surface area of the geothermal field. Coordinates are reported in UTM (Zone 16P).

currently sparse $\mathrm{Hg}$ database for gases from volcanogenic origin worldwide (Weissberg \& Rohde 1978; Cox 1983; Siegel \& Siegel 1984; Varekamp \& Buseck 1986; Nakagawa 1999; Engle et al. 2006). Previous research suggested that steam condensation can affect GEM to other chemicals ratios (Varekamp \& Buseck 1981, 1986). In this study, we did not attempt to measure $\mathrm{Hg}$ concentration in fumarolic steam condensates, so we cannot rule out the possibility that our derived $\mathrm{Hg}$ emissions are underestimating the real emissions to some extent
(Nakagawa 1999; Aiuppa et al. 2007). The release of $\mathrm{Hg}$ from previously enriched substrates as a result of geothermal processes has not been determined at Las Pailas and Las Hornillas, but it might contribute significantly in estimating the cumulative $\mathrm{Hg}$ flux from geothermal systems as recently demonstrated elsewhere (e.g. Nea Kameni fumarolic fields, Greece; Sulphur Banks, Hawaii, Varekamp \& Buseck 1986; Miravalles volcano, Melián et al. 2004; United States, Engle et al. 2006; la Solfatara, Pozzuoli, Bagnato et al. 2009a, 2013). 


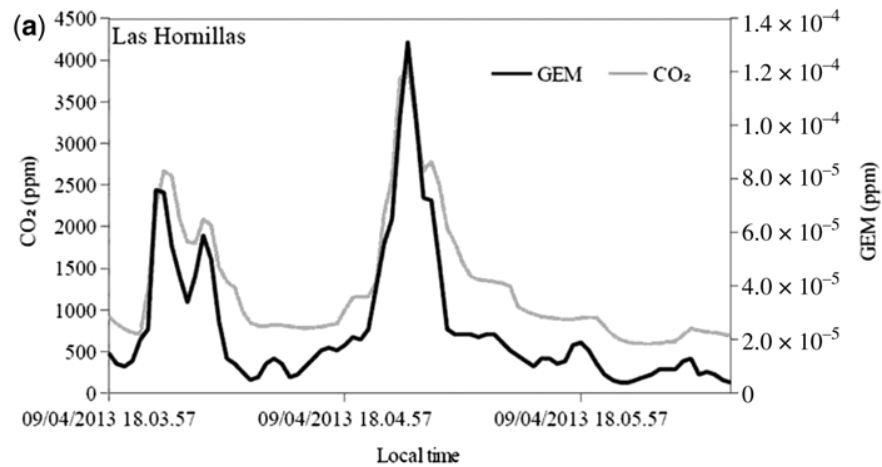

(b)

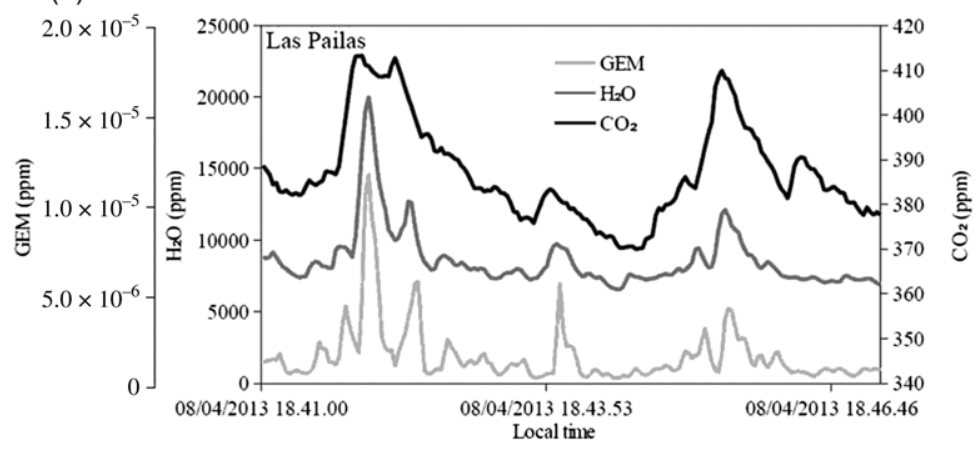

Fig. 4. Temporal variations in $\mathrm{CO}_{2}$ (grey line), GEM (black line) and $\mathrm{H}_{2} \mathrm{O}$ (light grey line) measured with MultiGAS and Lumex, respectively at (a) Las Hornillas and (b) Las Pailas geothermal systems. The positive temporal correlation exhibited by the two species may support $\mathrm{CO}_{2}$ as potential carrier gas in transporting GEM in magmatic systems.

\section{The importance of $\mathrm{Hg} / \mathrm{S}$ ratio}

Concentrations of gaseous plume species at crater rims depend on both volcanic (gas flux) and nonvolcanic factors (extent of mixing and dilution in the vent, wind speed and direction); comparing the concentrations of species between different volcanoes is therefore not necessarily meaningful and it is more useful to compare ratios of various species. A large variety of chemical methods have been used in the past to quantify $\mathrm{Hg} / \mathrm{SO}_{2}$ proportions in volcanic emissions (e.g. Varekamp \& Buseck 1981; Nakagawa 1999; Ferrara et al. 2000; Bagnato et al. 2007), the majority of which require complex and time-consuming post-sampling analytical determinations in a laboratory, precluding real-time measurement and limiting the acquisition of robust datasets. The literature reported $\mathrm{Hg} / \mathrm{SO}_{2}$ mass ratios in volcanic emissions span four orders of magnitude (Pyle \& Mather 2003), including fumarolic condensates and vapours which dominate the available data. Fumarolic emissions may differ in composition from the high-temperature gases released directly from magma (Symonds et al. 1992). The uncritical use of fumarolic $\mathrm{Hg} / \mathrm{SO}_{2}$ as a proxy for magmatic $\mathrm{Hg} / \mathrm{SO}_{2}$ will underestimate volcanic $\mathrm{Hg}$ emission rates because $\mathrm{SO}_{2}$ is mostly from high-temperature sources (magmatic), while low-temperature fumarolic environments are to some extent enriched in $\mathrm{H}_{2} \mathrm{~S}$ (Pyle \& Mather 2003; Aiuppa et al. 2007). This means that in estimating the $\mathrm{Hg}$ emission flux, it is more appropriate to consider the $\mathrm{Hg} / \mathrm{S}_{\text {tot }}$ ratio (where $\mathrm{S}_{\text {tot }}=\mathrm{SO}_{2}+$ $\mathrm{H}_{2} \mathrm{~S}$ ) rather than the single S-species. Some recent assessments of global volcanic emissions of $\mathrm{Hg}$ have not properly accounted for this (Unni et al. 1978; Nriagu 1989; Ferrara et al. 2000). These considerations are especially important as the most significant factor that influences volcanic $\mathrm{Hg}$ flux estimates is the value of $\mathrm{Hg} / \mathrm{SO}_{2}$ that is adopted in the calculation. The variability we found in the averaged GEM concentrations (see Table 2) measured in gaseous emissions of the investigated volcanoes strongly highlights the importance of using $\mathrm{Hg} / \mathrm{S}$ ratios to compare volcanic emissions. Given the uncertainties associated with the gold-trap technique, we found a good agreement by comparing atmospheric Lumex ${ }^{\circledR} /$ MultiGAS measurements and those made with gold-traps/filterpacks in determining $\mathrm{Hg} / \mathrm{SO}_{2}$ mass ratios (see Table 2, especially for Poás and Turrialba volcanoes). Most of the measured $\mathrm{GEM} / \mathrm{SO}_{2}$ range from $10^{-6}$ to $10^{-5}$, 


\section{E. BAGNATO ET AL.}

except for Aso fumaroles, Mutnovsky Active Funnel plume and Poás volcano which displays the lowest mass ratios ranging from $10^{-8}$ to $10^{-7}$ (see Table 2). At Rincón de la Vieja volcano, we measured a mean fumarolic $\mathrm{GEM} / \mathrm{SO}_{2}$ ratio of c. $3.5 \times 10^{-6}$ (range $4.3-2.7 \times 10^{-6}$; Table 2). The GEM $/ \mathrm{SO}_{2}$ mass ratios estimated in the plumes of the North East Crater and Bocca Nuova at Mt Etna (3.4-7.1 $\times 10^{-6}$ respectively; Table 2) are comparable to the mean value reported by Bagnato et al. (2007) $\left(\right.$ c. $\left.8.8 \times 10^{-6}\right)$. Finally, at
Las Pailas and Las Hornillas we measured GEM/ $\mathrm{SO}_{2}$ of $1.68 \times 10^{-5}$ and $4.1 \times 10^{-6}$, respectively.

A broad correlation was found by plotting GEM versus $\mathrm{SO}_{2(\mathrm{~g})}$ concentrations $\left(\mathrm{Hg} / \mathrm{SO}_{2} c .10^{-7}\right.$ to $10^{-5}$ ) in the plume of active degassing volcanoes from arc and non-arc setting (taken from both literature and this study; Fig. 5). The most likely reason for the differences observed in $\mathrm{GEM} / \mathrm{SO}_{2}$ mass ratios among the reported volcanoes from similar settings may simply be compositional variability (i.e. $\mathrm{Hg}$ and $\mathrm{S}$ contents; Fig. 5). Further, since $\mathrm{Hg}$

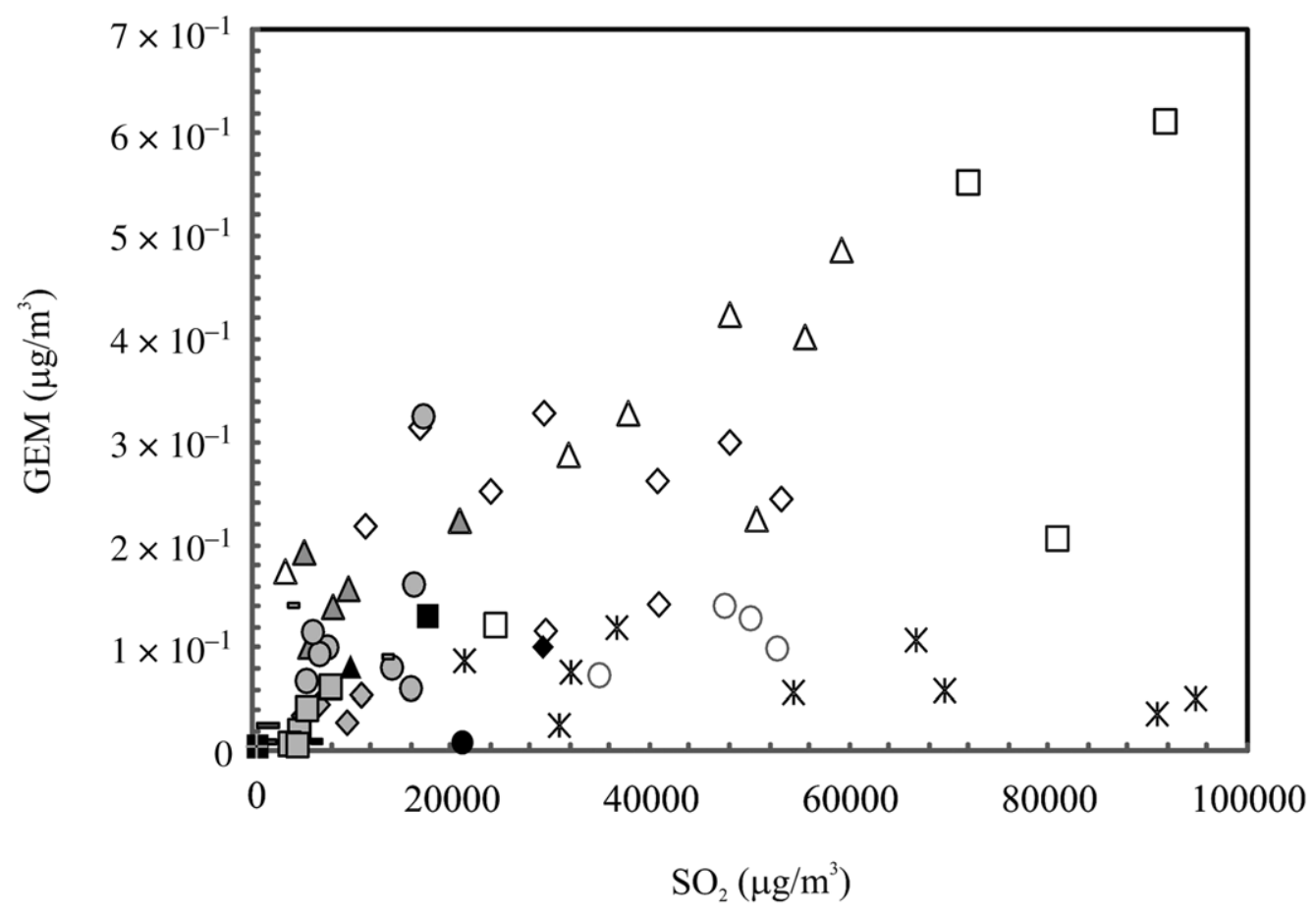

$\diamond$ Etna NEC (Bagnato et al. 2007)

$\square$ Nyiragongo (Bagnato et al. 2011)

$\triangle$ Masaya (Witt et al. 2008)

- Yasur (Bagnato et al. 2011)

- La Soufriere (Bagnato et al. 2011)

O Vulcano Isl. (Aiuppa et al. 2007)

Etna BN (this study)

$\boldsymbol{\Delta}$ Turrialba (this study)

Horely (this study) $\triangle$ Etna VOR (Bagnato et al. 2007)

* Hawai Halema 'uma 'u vent (Mather et al. 2012)

Miyakejima (Bagnato et al. 2011)

Asama (Bagnato et al. 2011)

Stromboli (Bagnato et al. 2011)

Etna NEC (this study)

Mutnovsky (this study)

Aso (this study)

Fig. 5. Scatter plot of gaseous elemental mercury $(\mathrm{GEM}) \mathrm{v} . \mathrm{SO}_{2(\mathrm{~g})}$ concentrations in the vent plumes of active volcanoes from arc and non-arc volcanism (grey filled symbols and black open symbols, respectively) $\left(\mathrm{GEM} / \mathrm{SO}_{2}\right.$ ranging from $10^{-7}$ to $10^{-5}$; see Table 2). Our original data (black filled symbols) are set in the context of published volcanic gas compositions. Arc-volcanism setting: Masaya (Witt et al. 2008a), Miyakejima, Yasur, Stromboli, Asama, La Soufriere (Bagnato et al. 2011), Vulcano island (Aiuppa et al. 2007); non arc-volcanism setting: Etna NEC and Etna VOR (Bagnato et al. 2007), Nyiragongo (Bagnato et al. 2011), Hawai Halema'uma'u vent (Mather et al. 2012). 


\section{MERCURY FLUXES FROM VOLCANIC AND GEOTHERMAL SOURCES}

and $\mathrm{SO}_{2}$ have different solubility in silicate melts, they will be fractionated during magmatic degassing, implying that $\mathrm{Hg} / \mathrm{SO}_{2}$ will be significantly changing in both time and space. Volcanoes with acidic lakes, such as Poàs and Rincón de la Vieja, can also fractionate the $\mathrm{Hg} / \mathrm{SO}_{2}$ through scrubbing in the lakes of both $\mathrm{SO}_{2}$ and $\mathrm{Hg}$ as $\mathrm{H}_{2} \mathrm{SO}_{4}$ and $\mathrm{HgCl}_{2}$, respectively (Symonds et al. 2001; Shinohara et al. 2010). In such a case, the gaseous emanations from the lake will be fractionated in $\mathrm{Hg}$ / $\mathrm{SO}_{2}$ as a result of $\mathrm{SO}_{2}$ or $\mathrm{Hg}$ dissolution, or both. There is of course a need for continuing work to characterize both volcanic lake evasion fumes and low- and high-temperature volcanic emissions and to establish the factors which control the $\mathrm{Hg} / \mathrm{S}$ ratios at different degassing volcanoes. Previous estimates of the global non-explosive volcanic $\mathrm{Hg}$ flux have used $\mathrm{Hg} / \mathrm{SO}_{2}$ ratios between $10^{-7}$ and $10^{-5}$ (Varekamp \& Buseck 1986; Nriagu 1989; Ferrara et al. 2000; Nriagu \& Becker 2003) with $10^{-6}$ as the best representative of gas emissions from quiescent open-conduit degassing volcanoes (Fig. 6). In general, most of our GEM/SO ${ }_{2}$ data from continuous degassing are in agreement with this ratio (Figs $6 \&$ 7), and are similar to the value reported in Varekamp \& Buseck's (1986) global estimate for passive emissions from non-erupting volcanoes $\left(3.7 \times 10^{-6}\right)$. Our data also fall within the range of best estimates $\left(10^{-4}\right.$ to $\left.10^{-6}\right)$ proposed by Pyle \& Mather (2003) for non-explosive volcanic degassing and are also in agreement with the ratios found at other passive degassing volcanoes (see Tables 2 \& 3; Fig. 7). However, our data together with most of the reported GEM/SO $\mathrm{S}_{2}$ in the literature should probably be considered as the lower bounds because they mainly refer to passive emissions from non-erupting volcanoes; these are lower than the ratios measured during explosive eruptions which are also often accompanied by considerable $\mathrm{SO}_{2}$ emission (such as those documented for Kilauea, Arenal and Mt St Helens volcanoes; GEM $/ \mathrm{SO}_{2}$ from $10^{-4}$ to $10^{-3}$; Varekamp \& Buseck 1981; Ballantine et al. 1982; Fig. 7). Previous estimates of $\mathrm{Hg} / \mathrm{SO}_{2}$ ratios from explosive volcanic eruptions gave values varying much more, between $10^{-2}$ and $10^{-5}$ (Buat-Menard \& Arnold 1978; Varekamp \& Buseck 1981; Ballantine et al. 1982; Shuster et al. 2002), suggesting that emissions from large explosive eruptions are rich in $\mathrm{Hg}$.

By comparing plume GEM $/ \mathrm{SO}_{2}$ mass ratios to the corresponding plume $\mathrm{H}_{2} \mathrm{O} / \mathrm{SO}_{2}$ ratios (Fig. 8 ; see Tables $1 \& 2$ for data sources), most of the open conduit 'arc' volcanoes (grey filled triangles in Fig. 8) show an overall positive correlation between $\mathrm{H}_{2} \mathrm{O} / \mathrm{SO}_{2}$ and $\mathrm{GEM} / \mathrm{SO}_{2}$ ratios $\left(r^{2}=0.8\right)$. This may suggest that gas emissions in subduction zones contain more $\mathrm{Hg}$ (relative to $\mathrm{SO}_{2}$ ) than those from divergent (or within-plate) plate volcanism, as also previously suggested by some authors (Kim et al. 2000; Bagnato et al. 2011). Data from Rincón de la Vieja volcano as well as the two geothermal fields (Las Pailas and Las Hornillas) fall outside the main trend exhibited

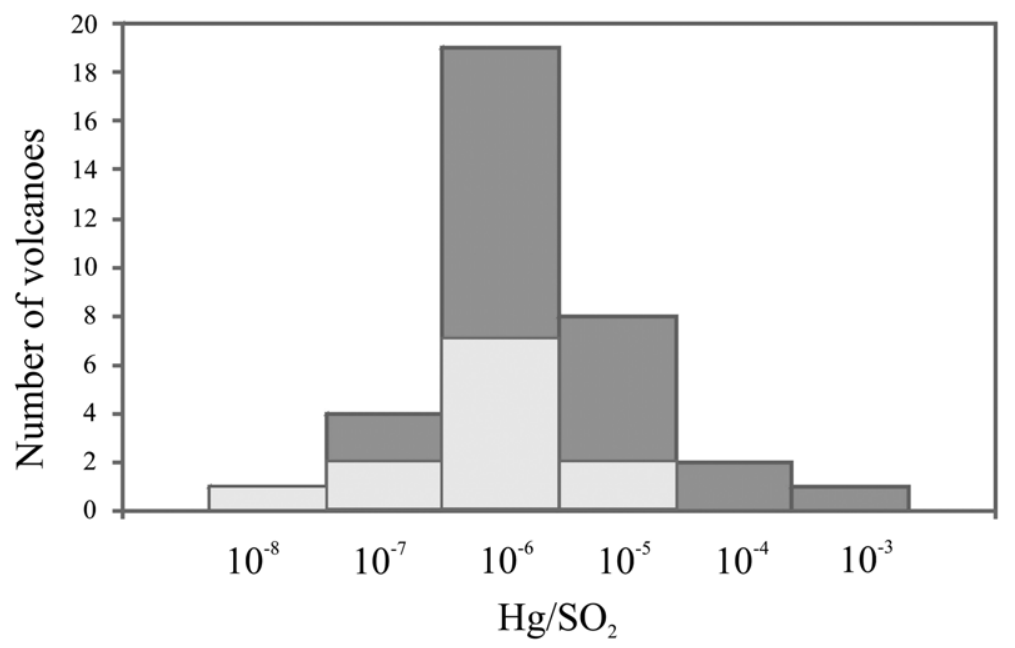

Fig. 6. Summary of measured GEM/SO mass ratios in the volcanic bulk plume, compiled from this work (light grey bars) and published data (as reported in Fig. 5). The compilation strongly supports $10^{-6}$ to $10^{-5}$ for the $\mathrm{Hg} / \mathrm{SO}_{2}$ plume ratio from quiescent degassing volcanoes as representative of gas emissions from the open-conduit degassing volcanoes. 


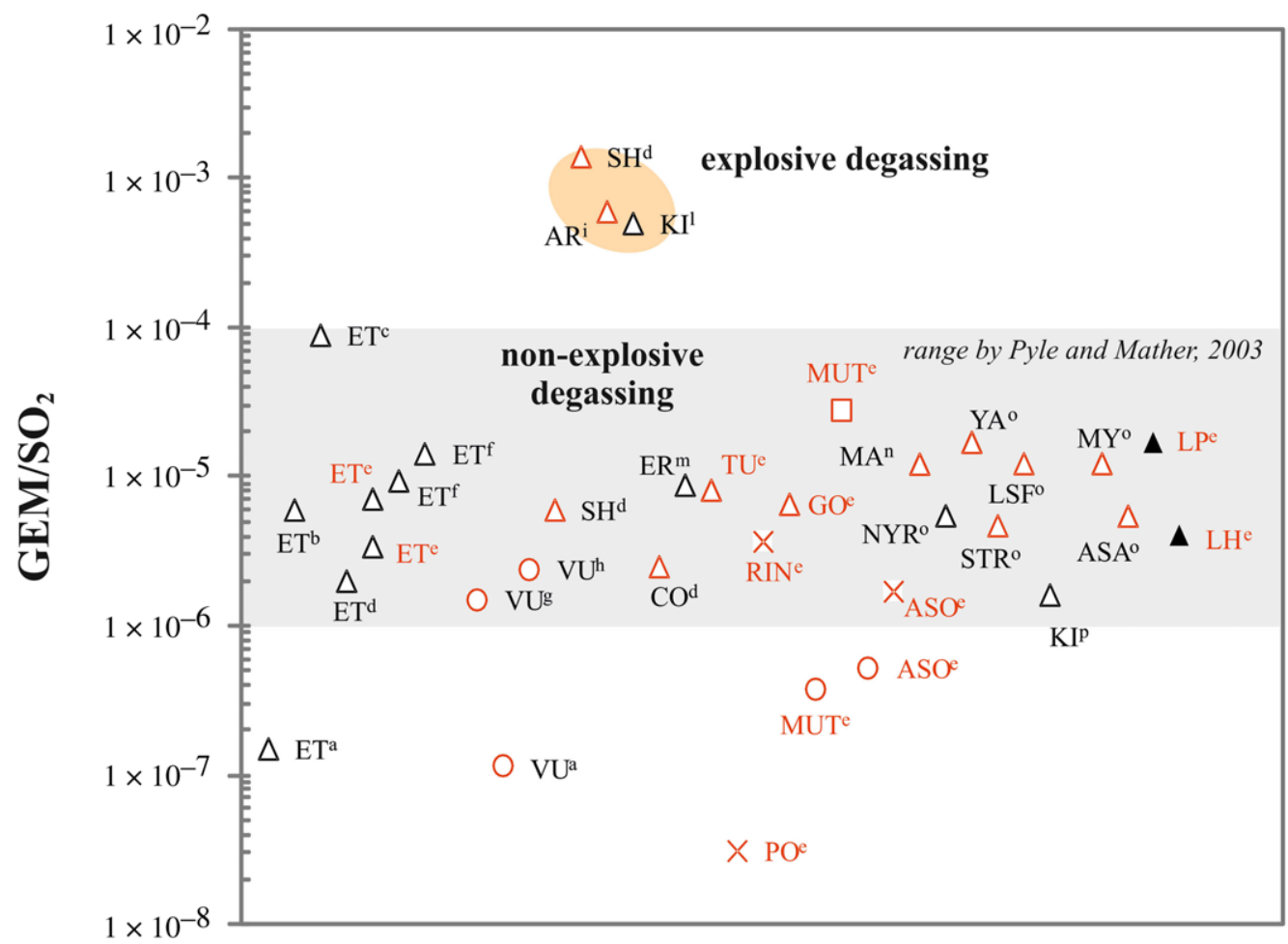

\section{$\triangle$ open-conduit arc-volcanism \\ $\triangle$ open-conduit non -arc volcanism \\ closed-conduit arc-volcanism volcanic lakes \\ geothermal fields}

Fig. 7. Summary of measured $\mathrm{GEM} / \mathrm{SO}_{2}$ mass ratios in worldwide volcanic emanations. The graph was constructed from results obtained in this study (red text), and previously published data (black text). A distinction was made between the emission type plotted in the graph to show open/closed conduit, arc/non-arc volcanism, volcanic lake evasion and geothermal fields. Most of the reported GEM/ $\mathrm{SO}_{2}$ values are lower than those measured for Kilauea, Arenal $\left(10^{-4}\right)$ and Mt St Helens volcanoes, during explosive eruptions (pink-coloured area). Reported data are taken from: ${ }^{a}$ Ferrara et al. (2000); ${ }^{\mathrm{b}}$ Dedeurwaerder et al. (1982); ${ }^{\mathrm{C}}$ Buat-Menard \& Arnold (1978); ${ }^{\mathrm{d}}$ Varekamp \& Buseck (1986); ${ }^{\mathrm{e}}$ this work; ${ }^{\mathrm{f}}$ Bagnato et al. (2007); ${ }^{\mathrm{g}}$ Bichler et al. (1995); ${ }^{\mathrm{h}}$ Aiuppa et al. (2007); ${ }^{\mathrm{i}}$ Ballantine et al. (1982); ${ }^{1}$ Siegel \& Siegel (1984); ${ }^{\mathrm{m}}$ Kyle et al. (1990); ${ }^{\mathrm{n}}$ Witt et al. (2008a, b); ${ }^{\circ}$ Bagnato et al. (2011); ${ }^{\mathrm{p}}$ Mather et al. (2012). ET, Etna; ER, Erebus; PO, Poás; ASO, Aso; MUT, Mutnovsky; GO, Gorely; MA, Masaya; KI, Kilauea; NY, Nyiragongo; YA, Yasur; TU, Turrialba; ASA, Asama; CO, Colima; VU, Vulcano Island; STR, Stromboli; RIN, Rincón de la Vieja; LSF, La Soufriere Hill; MY, Miyakejima; SH, St Helens; AR, Arenal; LP, Las Pailas; LH, Las Hornillas. The grey-coloured area shows the typical range of GEM/ $\mathrm{SO}_{2}$ ratios for continuous degassing volcanoes, as suggested by Pyle \& Mather (2003).

by the other volcanoes (Fig. 8). We note that for the former, it is likely that either the sulphur scrubbing action in the acid lakes or the distance from which we sampled gases may have influenced the $\mathrm{H}_{2} \mathrm{O} / \mathrm{SO}_{2}$ and $\mathrm{GEM} / \mathrm{SO}_{2}$ values. To date however, we are not able to say which of the two factors dominates. The excess of water detected in the gaseous emissions at Las Hornillas and Las Pailas geothermal fields may explain the low estimated $\mathrm{GEM} / \mathrm{H}_{2} \mathrm{O}$ mass ratios at these locations (black filled triangles in Fig. 8). More data are required to explore this relationship further, however. A stronger correlation between GEM and $\mathrm{SO}_{2}$ is evident for samples collected within plate/rift volcanism (Figs $5 \& 8$ ), in agreement with their similar degassing behaviour.

In arc-volcanism the origin of $\mathrm{Hg}$ can be manifold and fairly hard to understand. Metals released by gaseous discharges in volcanic arcs are ultimately sourced in the heterogeneous mantle wedge 
Table 3. Literature $\mathrm{Hg} / \mathrm{SO}_{2}$ mass ratios for active volcanoes worldwide

\begin{tabular}{|c|c|c|}
\hline Volcano & $\mathrm{Hg} / \mathrm{SO}_{2}$ & References \\
\hline Etna's bulk degassing & $8.9 \times 10^{-5}$ to $1.5 \times 10^{-7}$ & $\begin{array}{l}\text { Dedeurwaerder } \text { et al. (1982), } \\
\text { Varekamp \& Buseck (1986), } \\
\text { Ferrara et al. }(2000)\end{array}$ \\
\hline Etna North East's fumaroles & $2 \times 10^{-6}$ & Varekamp \& Buseck (1986) \\
\hline Colima & $2.5 \times 10^{-6}$ & Varekamp \& Buseck (1986) \\
\hline Vulcano Island & $1.16 \times 10^{-7}$ to $2.4 \times 10^{-6}$ & $\begin{array}{l}\text { Ferrara et al. (2000), Aiuppa et al. } \\
\quad(2007) \text {, Zambardi et al. (2009) }\end{array}$ \\
\hline Mt Erebus & $8.8 \times 10^{-6}$ & Kyle et al. (1990) \\
\hline White Island & $2.9 \times 10^{-6}$ & Wardell et al. (2008) \\
\hline Mt Shasta & $39 \times 10^{-6}$ & Varekamp \& Buseck (1986) \\
\hline Mt Hood & $7.1 \times 10^{-6}$ & Varekamp \& Buseck (1986) \\
\hline Mt St Helens & $6.0 \times 10^{-6}$ & Varekamp \& Buseck (1986) \\
\hline
\end{tabular}

beneath volcanoes (Jenner et al. 2010; Stracke 2012) by processes involving volatile release from the underlying hydrated subducting slab and entrained oceanic sediment (Mungall 2002; Labanieh et al. 2012; Henley \& Berger 2013). More data are required to better explore $\mathrm{Hg}$ behaviour from volcanoes where a subduction component is involved in magmagenesis; recent studies (Pyle \& Mather 2009) suggested that a significant component of $\mathrm{Hg}$ in volcanic emissions may originate from the subducting slab, as observed for other elements such as $\mathrm{Br}, \mathrm{Cl}$ and $\mathrm{I}$ in volcanic emissions.

By putting our new data into the context of published volcanic gas compositions from various geodynamic settings (arc volcanism and within plate/ rift volcanism; Fig. 9, data source in Tables 1 \& 2 ), we find an extremely variable composition ranging from $\mathrm{Hg}$ to $\mathrm{H}_{2} \mathrm{O}$-rich, respectively. The $\mathrm{Hg}$ rich end-member of the triangular plot shown in Figure 9 corresponds to the 1980 Mt St Helens explosive eruption (SH), characterized by fairly high $\mathrm{Hg}$ to sulphur mass ratio $\left(3.3 \times 10^{-3}\right.$; Varekamp \& Buseck 1986) which differs significantly from the ratio which usually characterizes the phase of passive degassing of the volcano $\left(6 \times 10^{-6}\right.$; Varekamp \& Buseck 1986). Gaseous emissions from Rincón de la Vieja volcano (RIN) are $\mathrm{H}_{2} \mathrm{O}$-rich and poor in sulphur and $\mathrm{Hg}$, probably due to the strong gas scrubbing by the lake and/or the high air dilution of the collected fumes. Intermediate compositions identify no clear trend and emphasize the presence of a compositional gap for sulphur-poor, $\mathrm{Hg}$ - and $\mathrm{H}_{2} \mathrm{O}$-rich volcanic gases. Water in volcanic gas represents an intrinsically highly variable parameter affected by condensation at numerous sites (fractures, hydrothermal systems, lakes and atmosphere), and its variability in this dataset is not surprising (as confirmed by the highly variable $\mathrm{H}_{2} \mathrm{O} / \mathrm{S}_{\text {tot }}$ ratios). Gases from closedconduit volcanoes in a fumarolic stage of activity and from volcanic lakes of arc-volcanism (i.e. Poás, Rincón de la Vieja, Mutnovsky and Aso) show very low $\mathrm{Hg}$ contents, probably due either to (1) the role played by the omnipresent wall-rock-gas and water-gas interactions which potentially favour $\mathrm{Hg}$ deposition in the hydrothermal envelope, or (2) the lake's gas scrubbing, respectively. Although limited, our data however suggest that there is no clear $\mathrm{Hg} / \mathrm{S}_{\text {tot }}$ and $\mathrm{Hg} / \mathrm{H}_{2} \mathrm{O}$ dependence on volcanic setting, but further detailed investigations are required.

\section{Hg emission fluxes from volcanic degassing}

Mercury emission rates from volcanoes are usually assessed by scaling the determined GEM/ $\mathrm{SO}_{2}$ to the simultaneously determined $\mathrm{SO}_{2}$ emission rates. The volcanic $\mathrm{Hg}$ emissions inventory is summarized in Table 2, where $\mathrm{Hg}$ fluxes from the literature with relevant data sources are also reported. The lowest $\mathrm{Hg}$ flux $\left(0.002 \mathrm{t} \mathrm{a}^{-1}\right)$ in our dataset is derived for Poás volcano, followed by Aso (c. $\left.0.33 \mathrm{t} \mathrm{a}^{-1}\right)$, Mutnovsky $\left(0.71 \mathrm{t} \mathrm{a}^{-1}\right)$, Gorely $\left(0.9 \mathrm{t} \mathrm{a}^{-1}\right)$, Turrialba $\left(2.4 \mathrm{t} \mathrm{a}^{-1}\right)$ and Etna (4.2 $\mathrm{t}$ $\left.\mathrm{a}^{-1}\right)$. While our estimates of $\mathrm{Hg}$ flux in the plumes of Aso and Etna volcanoes are comparable to those reported in the literature by previous authors $(c .0 .3$ and $5.4 \mathrm{t} \mathrm{a}^{-1}$, respectively; Andres \& Kasgnoc 1998; Bagnato et al. 2007), our bulk $\mathrm{Hg}$ emission flux measured at Mutnovsky volcano $\left(0.71 \mathrm{t} \mathrm{a}^{-1}\right)$ is about one order of magnitude higher than the value proposed by Taran et al. (1992) of $0.05 \mathrm{t} \mathrm{a}^{-1}$. The difficult meteorological conditions encountered on the top of Rincón de la Vieja volcano in April 2013 did not allow us to estimate $\mathrm{SO}_{2}$ emissions needed for calculating the $\mathrm{Hg}$ flux. No data on $\mathrm{SO}_{2}$ flux related to Rincon's recent degassing activity are available; $\mathrm{Hg}$ emission rate from this volcano has not been included in our calculation of the cumulative flux from active volcanism. 


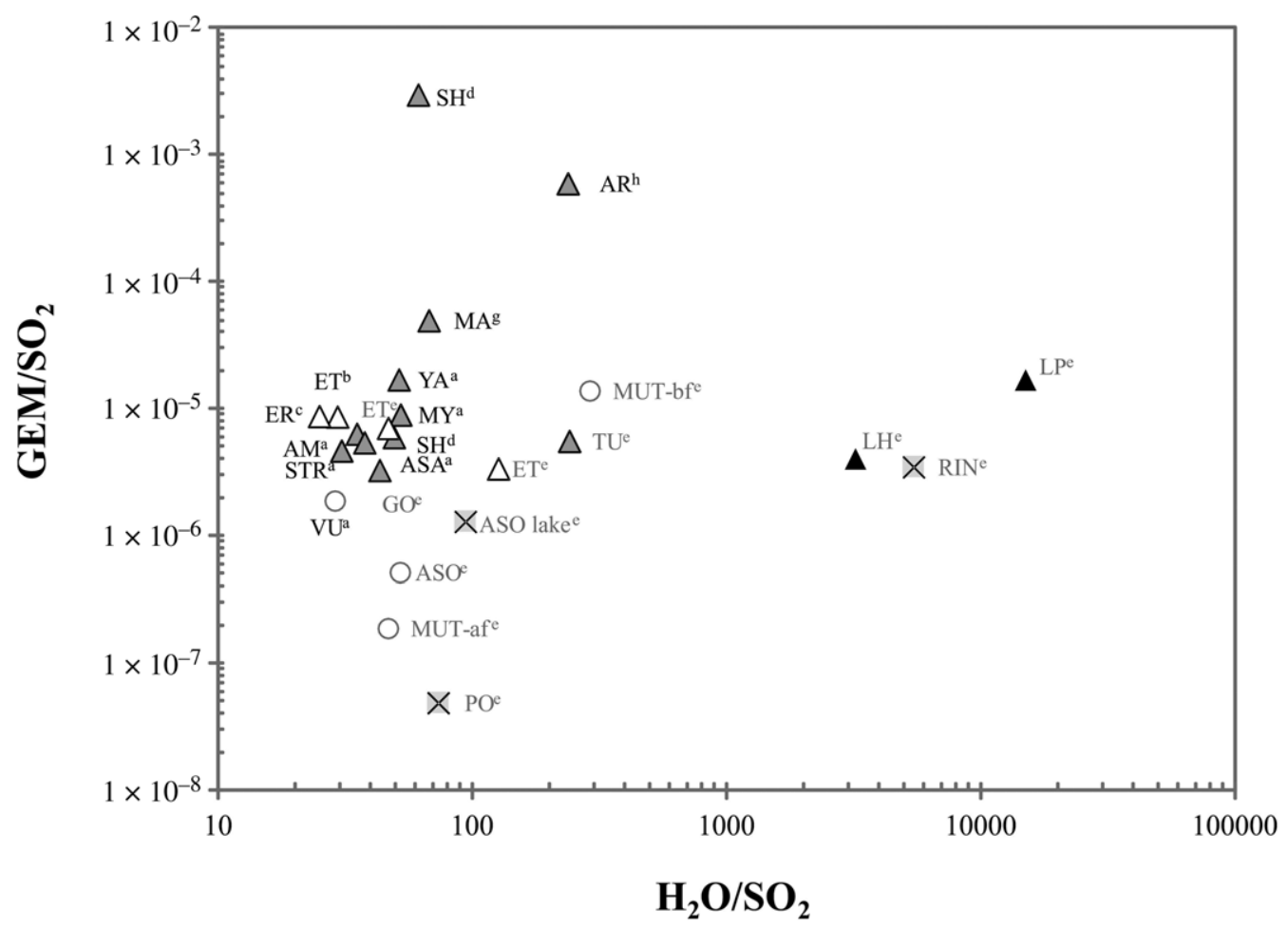

\section{$\triangle$ open-conduit arc-volcanism $\bigcirc$ closed-conduit arc-volcanism $\triangle$ open-conduit non-arc volcanism geothermal fields}

Fig. 8. Scatter plots of GEM/ $\mathrm{SO}_{2}$ (mass) ratio v. $\mathrm{H}_{2} \mathrm{O} / \mathrm{SO}_{2}$ (molar) ratio of arc (grey symbols) and non-arc (black open triangles) volcanoes. The graph was constructed from results obtained in this study (grey text) and previously published data (black text). A distinction was made between the emission type plotted in the graph to show open/closed vent, arc/non-arc volcanism, volcanic lake evasion and geothermal fields. The diagram suggests that there is some difference between the GEM/SO $\mathrm{SO}_{2}$ in arc and non-arc setting (see Table 2). 'Arc' volcanoes show an overall positive correlation between $\mathrm{H}_{2} \mathrm{O}$ content and $\mathrm{GEM} / \mathrm{SO}_{2}$ ratios, which might suggest that gas emissions in subduction zones may contain more $\mathrm{Hg}$ (relative to $\mathrm{SO}_{2}$ ) than those from divergent (or within-plate) plate volcanism. Literature $\mathrm{H}_{2} \mathrm{O} / \mathrm{SO}_{2}$ data and GEM/ $\mathrm{SO}_{2}$ mass ratios are from ${ }^{\mathrm{a} B a g n a t o}$ et al. (2011) (NY, Nyiragongo; YA, Yasur; AM, Ambrym; STR, Strombolim; ASA, Asama; MY, Miyakejima; VU, Vulcano); ${ }^{\mathrm{b}}$ Bagnato et al. (2007) (ET, Etna); ${ }^{\text {CKyle }}$ et al. (1990) (ER, Erebus); ${ }^{\mathrm{d}}$ Varekamp \& Buseck (1986) (SH, St Helens); ${ }^{\mathrm{e}}$ this study (ET, Etna; PO, Poás; TU, Turrialba; RIN, Rincón de la Vieja; LH, Las Hornillas; LP, Las Pailas; ASO, Aso; MUT, Mutnovsky; GO, Gorely). $\mathrm{Hg}_{\text {and }} \mathrm{H}_{2} \mathrm{O}$ concentrations have been multiplied and divided, respectively, for a certain factor in order to improve the representation of data inside the graph.

The large spread of our estimated $\mathrm{Hg}$ fluxes reflects the variable $\mathrm{GEM} / \mathrm{SO}_{2}$ ratios $\left(10^{-5}\right.$ to $10^{-8}$ ) exhibited by the investigated volcanoes and reveals variability in the $\mathrm{SO}_{2}$ mass flux and hence in the underlying mode of degassing. We stress that data presented here refer to volcanoes in a state of passive degassing activity, and that the above-cited values have to be considered as a lower bound (Table 2). Our calculations confirm that the continuous year-on-year emission from passively degassing volcanoes is relatively small if compared to explosive eruptions, which are usually accompanied by considerable $\mathrm{SO}_{2}$ emission (e.g. 1991 Pinatubo eruption, Ansmann et al. 1997; 1980 Mt St Helens eruption, Varekamp \& Buseck 1981). The most significant single-event emissions are those associated with rare, large explosive eruptions occurring once or twice per century 


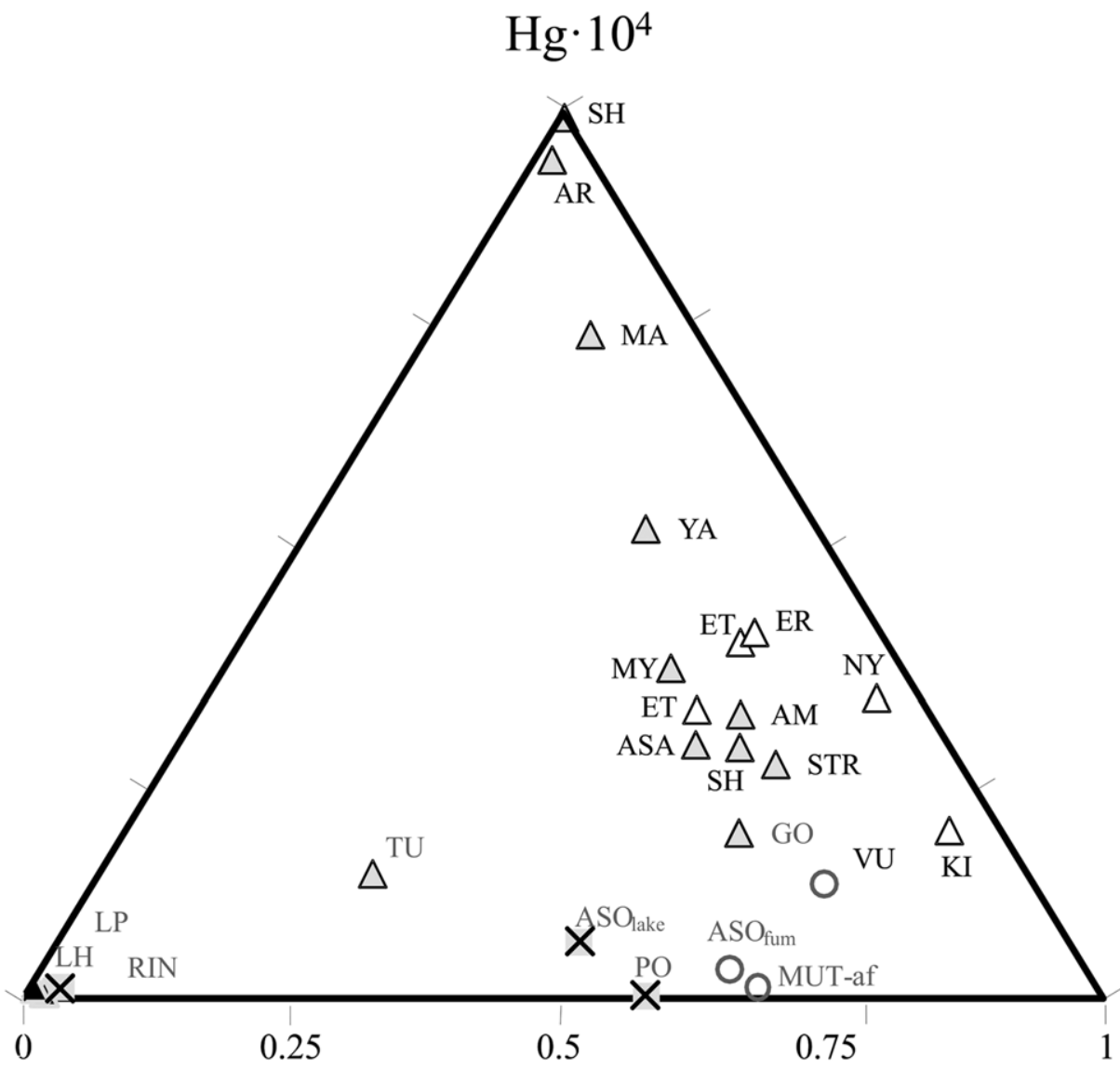

\section{$\triangle$ open-conduit arc-volcanism closed-conduit arc-volcanism $\triangle$ open-conduit non -arc volcanism geothermal fields}

Fig. 9. $\mathrm{SO}_{2}-\mathrm{H}_{2} \mathrm{O}-\mathrm{Hg}$ triangular plot of relative concentrations in the plumes of the investigated volcanoes. Our original data (grey text) are set in the context of published volcanic gas compositions from various geodynamic settings (black text). A distinction was made between the emission type plotted in the graph to show open/closed vent, arc/ non-arc volcanism, volcanic lake surface and geothermal fields. Our dataset exhibits a very variable composition ranging from $\mathrm{Hg}$ to $\mathrm{H}_{2} \mathrm{O}$-rich, respectively. The most $\mathrm{H}_{2} \mathrm{O}$-poor composition is observed at Nyiragongo and Kilauea (NY and KI). Stromboli (ST) gases are S-enriched (and depleted in $\mathrm{H}_{2} \mathrm{O}$ ) relative to 'typical' arc volcanic gases. The most $\mathrm{H}_{2} \mathrm{O}$-rich composition is observed at Rincón de la Vieja volcano while the most Hg-rich composition is observed for Mt St Helens explosive eruption in 1980 (SH) and Arenal (AR). Data source are taken from Tables 1 and 2 (this study) and from the literature: NY, Nyiragongo; YA, Yasur; AM, Ambrym; STR, Stromboli; ASA, Asama;

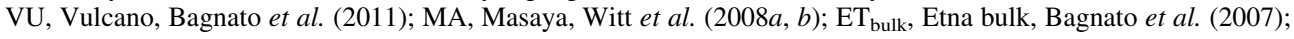
SH, St Helens, Varekamp \& Buseck (1986); AR, Arenal, Zimmer et al. (2004); Ballantine et al. (1982); ER, Erebus, Kyle et al. (1990).

which may instantaneously release 10 to $10^{3} \mathrm{Tg} \mathrm{SO}$ to the atmosphere (Pyle \& Mather 2003). Such large eruptions, which may release $>10^{3}$ to $10^{4} \mathrm{Mg} \mathrm{Hg}$ per event, are thought to significantly perturb the atmospheric $\mathrm{Hg}$ reservoir for c. $1 \mathrm{yr}$ (Pyle \& Mather 2003). 


\section{E. BAGNATO ET AL.}

\section{Hg emission fluxes from geothermal areas}

Mercury fluxes from geothermal areas are still poorly investigated and highly uncertain due to the complexity of making appropriate measurements of $\mathrm{Hg}$ emissions (e.g. Gustin 2003), but probably total $\leq 60 \mathrm{t} \mathrm{Hg} \mathrm{a}^{-1}$ (Varekamp \& Buseck 1986; Nriagu \& Becker 2003; Pyle \& Mather 2003). $\mathrm{The} \mathrm{Hg} / \mathrm{SO}_{2}$ approach for estimating $\mathrm{Hg}$ flux from volcanoes is not readily applicable to geothermal sources since the hydrothermal fluids are efficient sulphur scrubbers and there is no reliable method for measuring the flux of the dominant form of sulphur in these systems. In order to define $\mathrm{Hg}$ emission rates from Las Pailas and Las Hornillas geothermal fields, we interpolated (using the kriging contouring technique) the site-specific emission data to obtain contour maps of the $\mathrm{Hg}$ deposition flux which, by integration over the entire area covered by the survey (Fig. 3), allowed calculation of the integrated amount of $\mathrm{Hg}$ on a horizontal surface above the fumarolic areas $\left(\mathrm{ng} \mathrm{m}^{-1}\right)$. In order to calculate the $\mathrm{Hg}$ fluxes through these contoured area, the gas rising speed was extrapolated from in situ observations, displaying similar values to other not over-pressurized fumarolic emissions (Vulcano island, Tamburello et al. 2011; Campi Flegrei, Aiuppa et al. 2013; Nea Kameni, Bagnato et al. 2013). By considering a highly variable gas speed of $0.5-1.5 \mathrm{~m} \mathrm{~s}^{-1}$, we estimated a time-averaged total $\mathrm{Hg}$ flux ranging from 0.0008 to $0.0024 \mathrm{t} \mathrm{a}^{-1}$ for Las Pailas and from 0.004 to $0.012 \mathrm{t} \mathrm{a}^{-1}$ for Las Hornillas emissions (Table 2). The cumulative $\mathrm{Hg}$ flux released from both geothermal fields therefore ranges from 0.005 to $0.014 \mathrm{t} \mathrm{a}^{-1}$, appearing less important than the volcanic flux from continuous passive degassing and accounting for a very small proportion of the global $\mathrm{Hg}$ flux for geothermal emissions $\left(c .60 \mathrm{t} \mathrm{a}^{-1}\right.$; Varekamp \& Buseck 1986).

\section{Discussion}

Our measurements provide new information to the debate on $\mathrm{Hg}$ emission from active volcanism (Table 4). Worldwide volcanic $\mathrm{Hg}$ fluxes vary widely since volcanoes display a wide range of activity from continuous to short-lived events, matched perhaps by their diversity and geographic distribution. While it has long been known that volcanoes are important atmospheric sources of Hg (Varekamp \& Buseck 1981, 1986; Bagnato et al. 2007, 2009a, $b, 2011$ ), considerable uncertainty remains about the global volcanic $\mathrm{Hg}$ flux as the available data on volcanogenic $\mathrm{Hg}$ emissions is still sparse and incomplete (Pyle \& Mather 2003). Using the database on active and passively
Table 4. Previous estimates of global volcanic emission rates of mercury

\begin{tabular}{lc}
\hline Source & Emission rate, ton $\mathrm{Hg} \mathrm{a}^{-1}$ \\
\hline Pyle \& Mather (2003) & 75 (passive degassing) - 700 \\
(explosive activity) & 37.6 (passive degassing) - \\
Nriagu \& Becker (2003) & 57 (explosive activity) \\
& 30 (passive degassing) - 830 \\
Varekamp \& Buseck (1986) & $\quad$ (explosive activity) \\
Ferrara et al. (2000) & $20-1.3$ \\
Fitzgerald (1986) & 500 (range 30-1000) \\
Nriagu (1989) & $3-9.0$ \\
Unni et al (1978) & 100 \\
Anderson (1975) & \\
\hline
\end{tabular}

degassing volcanoes of the island arc type, Anderson (1975) came up with a value of $100 \mathrm{ta}^{-1}$. This estimate contrasts with a much lower flux of $3-9 \mathrm{t} \mathrm{a}^{-1}$ reported by Unni et al. (1978). From measurements of non-eruptive emissions at Kilauea (Hawaii), Colima (Mexico), Cascades volcanoes (Mt Shasta, Mt Hood and Mt St Helens) and Etna (Italy), Varekamp \& Buseck (1986) estimated the global $\mathrm{Hg}$ emission to be $830 \mathrm{t} \mathrm{a}^{-1}$. Based on measurements of $\mathrm{Hg} / \mathrm{S}$ ratios at three volcanoes (Kilauea, Etna and White Island), Fitzgerald (1986) was able to derive a global $\mathrm{Hg}$ flux of $20-90 \mathrm{t} \mathrm{a}^{-1}$. More recently, Ferrara et al. (2000) used the $\mathrm{Hg} / \mathrm{S}$ data for three volcanoes in Italy and Sicily (Etna, Stromboli and Volcano) to derive a global annual flux of only $0.6-1.3 \mathrm{ta}^{-1}$. Nriagu \& Becker (2003) derived a global $\mathrm{Hg}$ fluxes ranging from 37.6 (from degassing plume) to $57 \mathrm{t} \mathrm{a}^{-1}$ (from explosive activity). More recently, Pyle \& Mather (2003) suggested that $\mathrm{Hg}$ contributed annually by passively degassing volcanoes globally is of the order $75 \mathrm{ta}^{-1}$ (range $6-900 \mathrm{t} \mathrm{a}^{-1}$ ), or $700 \mathrm{ta}^{-1}$ (range $80-4000 \mathrm{t} \mathrm{a}^{-1}$ ) if considering the total time-averaged annual emission from degassing and erupting volcanoes. It is clear from Table 4 that there is a considerable range in estimates of the total $\mathrm{Hg}$ flux from volcanoes. The differences between previous $\mathrm{Hg}$ fluxes principally reflect the paucity of appropriate data on $\mathrm{Hg}$ in volcanic emissions and the ways that previous authors interpreted published data on volcanic $\mathrm{Hg}$.

Table 2 summarizes our new observations on passive volcanic degassing, as well as previously published work. If considering the 12 volcanoes reported in Table 2 and referring to plume emission type, they account for a cumulative $\mathrm{SO}_{2}$ flux of $c .6 \mathrm{Mt} \mathrm{a}^{-1}$ or $62 \%$ of the global $\mathrm{SO}_{2}$ volcanic emissions from continuously passive degassing volcanoes (9.7 $\mathrm{Mt} \mathrm{a}^{-1}$; Andres \& Kasgnoc 1998). We can therefore estimate $\mathrm{Hg}$ emissions in two ways: (1) a cumulative $\mathrm{Hg}$ emission flux based on $\mathrm{Hg} / \mathrm{SO}_{2}$ ratios and $\mathrm{SO}_{2}$ fluxes at these 12 individual volcanoes, which amounts to $56 \mathrm{t} \mathrm{a}^{-1}$; and (2) a 
global $\mathrm{Hg}$ emission flux based on the globally averaged $\mathrm{Hg} / \mathrm{SO}_{2}$ ratio of $7.8 \times 10^{-6}\left( \pm 1.5 \times 10^{-6} ; 1\right.$ SE, $n=13$ ) and the global volcanic $\mathrm{SO}_{2}$ flux of $9.7 \mathrm{Mt} \mathrm{a}^{-1}$ (Andres \& Kasgnoc 1998). While Andres \& Kasgnoc (1998) did not present an uncertainty budget associated with their $9.7 \mathrm{Mt} \mathrm{a}^{-1} \mathrm{SO}_{2}$ flux estimate, a second study on volcanic $\mathrm{SO}_{2}$ fluxes proposed an uncertainty of $35 \%$ relative standard deviation (Graf et al. 1997) and is widely considered as appropriate (Schmidt et al. 2012). By combining our updated average $\mathrm{Hg} / \mathrm{SO}_{2}$ plume mass ratio for quiescent volcanic activity of $7.8 \times$ $10^{-6}\left( \pm 1.5 \times 10^{-6} ; 1 \mathrm{SE}, n=13\right)$ (Table 2) and the uncertainties on $\mathrm{SO}_{2}$ flux we therefore obtain a global volcanic $\mathrm{Hg}$ flux from continuous passive degassing of $76 \pm 30 \mathrm{t} \mathrm{a}^{-1}$ (Table 2). Our estimate is similar to that of Pyle \& Mather (2003), but for the first time includes an estimate of uncertainty.

Since the global $\mathrm{SO}_{2}$ emission rate used in this calculation $\left(9.7 \mathrm{Mt} \mathrm{a}^{-1}\right.$; Andres \& Kasgnoc 1998) represents open-conduit passive degassing, the total $\mathrm{Hg}$ flux from volcanoes during strong eruptive events may be even larger than that provided by the reported data in this study (Roos-Barraclough et al. 2002; Schuster et al. 2002).

The measurements of gas emissions from closedconduit volcanoes in a fumarolic-stage of activity and geothermal emissions suggest a much smaller flux of $\mathrm{Hg}$ released from these activities. We estimated a cumulative $\mathrm{Hg}$ flux from three closedconduit volcanoes (Aso, Mutnovsky and Poás; this study) and both geothermal fields (Las Pailas and Las Hornillas; this study) of $c .1 \mathrm{t} \mathrm{a}^{-1}$ (Table 2). If we also consider $\mathrm{Hg}$ fluxes from various quiescent degassing closed-conduit volcanoes in a fumarolic stage of activity recently reported in literature (0.55-0.65 t a ${ }^{-1}$; Bagnato et al. 2011), our estimated cumulative $\mathrm{Hg}$ flux from closed-conduit volcanoes would increase to $c .1 .6 \mathrm{t} \mathrm{a}^{-1}$ (c. $2 \%$ of our estimate of the yearly global $\mathrm{Hg}$ emission from passive degassing volcanoes). Although comprising a marginal contribution to the global volcanic non-eruptive $\mathrm{Hg}$ emissions from closed-conduit degassing volcanoes, these new data represent the first available assessment of $\mathrm{Hg}$ emissions directly sampled at these locations. The minor $\mathrm{Hg}$ input from closedconduit volcanoes in fumarolic-stage of activity compared to open-conduit volcanoes mainly reflects different $\mathrm{SO}_{2}$ degassing rates and the role played by the omnipresent wall-rock-gas and water-gas interactions, which potentially favour $\mathrm{Hg}$ deposition in the hydrothermal envelope (Figs $5 \& 6$ ).

\section{Concluding remarks}

This study provides new information to expand the limited database of volcanic $\mathrm{Hg}$ emissions and allows some inferences to be made regarding the quality of previous estimates of global volcanic $\mathrm{Hg}$ inventories. A critical assessment of the published literature suggests that some global $\mathrm{Hg}$ emission estimates are likely to be significantly underestimated. We demonstrate that volcanic degassing is an important component of the global atmospheric Hg budget, even when only considering quiescent phases of volcanic activity. Using our dataset in tandem with literature information, we propose a mean $\mathrm{Hg} / \mathrm{SO}_{2}$ mass ratio of $c .7 .8 \times 10^{-6}$ $\left( \pm 1.5 \times 10^{-6} ; 1 \mathrm{SE}, n=13\right)$ from quiescent degassing volcanoes as representative of gas emissions from the open-conduit degassing volcanoes used in this study. Taking into account the uncertainty in global SO2 emissions, we derive a global volcanic $\mathrm{Hg}$ flux from quiescent volcanoes of $c .76$ $( \pm 30) \mathrm{t} \mathrm{a}^{-1}$, which is comparable to previous literature estimates. Our analysis suggests that volcanoes in a state of passive degassing represent an important contribution to global volcanic mercury emissions into the atmosphere. It is therefore likely that volcanic contributions to the global atmospheric $\mathrm{Hg}$ budget will be even more important during large eruptive events. For this reason, the measurement of $\mathrm{Hg}$ in eruptive gases is a priority for future research.

This work was supported by a research grant funded by the Universidad Nacional in Heredia, Costa Rica during March-April 2013. JES acknowledges funding from the European Research Council (ERC-2010-StG-20091028). The authors gratefully acknowledge the OVSICORI-UNA, Costa Rica for their logistic support in the field. The authors also wish to thank two anonymous reviewers for helpful comments on a previous version of the manuscript. Finally, EB thanks M. Liuzzo (INGV, sez. Palermo, Italy) and S. Calabrese (DiSTeM, Unipa) for their helpful contribution in sampling gases.

\section{References}

Aiuppa, A., Federico, C., Giudice, G., Gurrieri, S., Paonita, A. \& Valenza, M. 2004. Plume chemistry provides insights into the mechanisms of sulfur and halogen degassing at basaltic volcanoes. Earth and Planetary Science Letters, 222, 469-483.

Aiuppa, A., Federico, C. ET AL. 2005. Emission of bromine and iodine from Mount Etna volcano. Geochemistry, Geophysics, Geosystem, 6, Q08008, http://dx.doi.org/10.1029/2005GC000965

Aiuppa, A., Bagnato, E., Witt, M. L. I., Mather, T. A., Parello, F., Pyle, D. M. \& Martin, R. S. 2007. Realtime simultaneous detection of volcanic $\mathrm{Hg}$ and $\mathrm{SO}_{2}$ at La Fossa Crater, Vulcano (Aeolian Islands, Sicily). Geophysical Research Letters, 34, L21307, http://dx. doi.org/10.1029/2007GL030762

Aiuppa, A., Bertagnini, A., Métrich, N., Moretti, R., Di Muro, A., Liuzzo, M. \& TAmburello, G. 2010. A 


\section{E. BAGNATO ET AL.}

model of degassing for Stromboli volcano. Earth and Planetary Science Letters, 295, 195-204.

Aiuppa, A., Shinohara, H., Tamburello, G., Giudice, G., Liuzzo, M. \& Moretti, R. 2011. Hydrogen in the gas plume of an ope-vent volcano, Mount Etna, Italy. Journal of Geophysical Research, 116, B10204, http://dx.doi.org/10.1029/2011JB008461

AIUPPA, A., GIUDICE, G. ET AL. 2012. First volatile inventory for Gorely volcano, Kamchatka. Geophysical Research Letters, 39, L06307, http://dx.doi.org/10. 1029/2012GL051177

Aiuppa, A., Tamburello, G. ET AL. 2013. First observations of the fumarolic gas output from a restless caldera: implications for the current period of unrest (2005-2013) at Campi Flegrei. Geochemistry Geophysics Geosystems, 14, 4153-4169.

Allard, P., Carbonnelle, J. et AL. 1991. Eruptive and diffuse emissions of $\mathrm{CO}_{2}$ from Mount Etna. Nature, 351, 387-391, http://dx.doi.org/10.1038/351387a0

Allard, P., Behncke, B., D’Amico, S., Neri, M. \& Gambino, S. 2006. Mount Etna 1993-2005: anatomy of an evolving eruptive cycle. Earth-Science Reviews, 78, 85- 114 .

ANDERSON, A. T. 1975. Some basaltic and andesitic gases. Reviews of Geophysics and Space Physics, 13, 37-56.

Andres, R. J. \& Kasgnoc, A. D. 1998. A time averaged inventory of subaerial volcanic sulfur emissions. Journal of Geophysical Research, 103, $25251-25261$.

Ansmann, A., Mattis, I., Wandinger, U., Wagner, F., ReichardT, J. \& Deshler, T. 1997. Evolution of the Pinatubo aerosol: Raman Lidar observations of particle optical depth, effective radius, mass and surface area over Central Europe at $53.4^{\circ}$ N. Journal of the Atmospheric Science, 54, 2630-42641.

Ariya, P. A., Skov, H., Grage, M. M. L. \& Goodsite, M. E. 2008. Gaseous elemental mercury in the ambient atmosphere: review of the application of theoretical calculations and experimental studies for determination of reaction coefficients and mechanisms with halogens and other reactants. Advances in Quantum Chemistry, 55, 43-55.

Bagnato, E., Aiuppa, A. ET AL. 2007. Degassing of gaseous (elemental and reactive) and particulate mercury from Mount Etna volcano (Southern Italy). Atmospheric Environment, 41, 7377-7388, http://dx. doi.org/10.1016/j.atmosenv.2007.05.060

Bagnato, E., Parello, F., Valenza, M. \& Caliro, S. 2009a. Mercury content and speciation in the Phlegrean Fields volcanic complex: evidences from hydrothermal system and fumaroles. Journal of Volcanology and Geothermal Research, 187, 250-260.

Bagnato, E., Allard, P., Parello, F., Aiuppa, A., Calabrese, S. \& Hammouya, G. 2009b. Mercury gas emissions from La Soufrière Volcano, Guadeloupe Island (Lesser Antilles). Chemical Geology, 266, 276-282.

Bagnato, E., Aiuppa, A., Parello, F., Allard, P., Liuzzo, M., Giudice, G. \& Shinohara, H. 2011. New clues on mercury contribution from Earth volcanism. Bulletin of Volcanology, 73, 497-510, http://dx. doi.org/10.1007/s00445-010-0419-y

Bagnato, E., Tamburello, G., Aiuppa, A., Sprovieri, M., Vougioukalakis, G. E. \& Parks, M. 2013.
Atmospheric mercury emissions from substrate and fumaroles at Nea Kameni volcanic system, Santorini (Greece). Geochemical Journal, 47, 437-450.

Ballantine, D. S., Finnegan, D. L., Phelan, J. M. \& ZoLler, W. H. 1982. Measurement of $\mathrm{Hg} / \mathrm{S}$ ratios from five volcanoes. EOS Transaction, American Geophysical Union, 63, 1152.

Bichler, M., Poljank, K. \& Sortino, F. 1995. Determination and speciation of minor and trace elements in volcanic exhalation by NAA. Journal of Radioanalytical and Nuclear Chemistry, 92, 183-194, http://dx. doi.org/10.1007/BF02041722

Bluth, G. J. S., Shannon, J. M., Watson, I. M., Prata, A. J. \& Realmuto, V. J. 2007. Development of an ultra-violet digital camera for volcanic $\mathrm{SO}_{2}$ imaging. Journal of Volcanology and Geothermal Research, 161, 47-56, http://dx.doi.org/10.1016/j.jvolgeores. 2006.11.004

Buat-Menard, P. \& ARnold, M. 1978. The heavy metal chemistry of particulate matter emitted by Mount Etna volcano. Geophysical Research Letters, 5, 245-248.

Campion, R., Martinez-Cruz, M. et AL. 2012. Spaceand ground-based measurements of sulphur dioxide emissions from Turrialba Volcano (Costa Rica). Bulletin of Volcanology, 74, 1757-1770, http://dx.doi. org/10.1007/s00445-012-0631-z

CARR, M. J. 1984. Symmetrical and segmented variation of physical and geochemical characteristics of the Central American volcanic front. Journal of Volcanology and Geothermal Research, 20, 231-252.

Carr, M. J., Feigenson, M. D., Patino, L. C. \& Walker, J. A. 2003. Volcanism and geochemistry in Central America: progress and problems. In: EILER, J. (ed.) Inside the Subduction Factory. American Geophysical Union, Washington, 153-174.

Castro, S. 2002. Reservoir engineering studies in the Las Pailas geothermal field, Costa Rica. Geothermal Training in Iceland 2002, Report 4. UNU-GTP, Iceland.

Cheminée, J. M., Javoy, M. \& Delorme, H. 1983. Temperature and gas data from Turrialba. SEAN 08.01, Smithsonian Institution, http://www.volcano.si.edu/ world/volcano.cfm?vnum01405-070\&volpage0var\# sean_0801

Christenson, B. W. \& MroczeK, E. K. 2003. Potential reaction pathways of $\mathrm{Hg}$ in some New Zealand hydrothermal environments. Society of Economic Geology, 10, $111-132$.

Cox, M. E. 1983. Summit outgassing as indicated by radon, mercury, and $\mathrm{pH}$ mapping, Kilauea volcano, Hawaii. Journal of Volcanology and Geothermal Research, 16, 131-152.

DeDuerwaerder, H., Decadt, G. \& Baeyens, W. 1982. Estimations of mercury fluxes emitted by Mt Etna volcano. Bulletin of Volcanology, 45, 191-196.

Delmas, R. J., Kirchner, S., Palais, J. M. \& Petit, J. R. 1992. 1000 years of explosive volcanism recorded at the South Pole. Tellus, 44B, 335-350.

Engle, M. A., Gustin, M. S., Goff, F., Counce, D. A., JaniK, C. J., Bergfeld, D. \& Rytuba, J. J. 2006. Atmospheric mercury emissions from substrates and fumaroles associated with three hydrothermal systems in the western United States. Journal of 
Geophysical Research, 111, D17304, http://dx.doi. org/10.1029/2005JD006563

Ferrara, R., Mazzolai, B., Lanzillotta, E., Nucaro, E. \& Pirrone, N. 2000. Volcanoes as emission sources of atmospheric mercury in the Mediterranean basin. The Science of the Total Environment, 259, 115-121.

FitzGerald, W. F. 1986. Cycling of mercury between the atmosphere and oceans. In: BuAT-MÉnARD, P. (ed.) The Role of Air-Sea Exchange in Geochemical Cycling. D. Reider Publishing Co., Dordrecht, 363-408.

Friedli, H. R., Radke, L. F., Lu, J. Y., Banic, C. M., Leaitch, W. R. \& MacPherson, J. I. 2003. Mercury emissions from burning of biomass from temperate North American forests: laboratory and airborne measurements. Atmospheric Environment, 37, $253-267$.

Galle, B., Oppenheimer, C., Geyer, A., McGonigle, A. J. S., Edmonds, M. \& Horrocks, L. A. 2003. A miniaturised ultraviolet spectrometer for remote sensing of $\mathrm{SO}_{2}$ fluxes: a new tool for volcano surveillance. Journal of Volcanology and Geothermal Research, 119, 241-254.

Gherardi, F., Panichia, C., Yock, A. \& GerardoAваYA, J. 2002. Geochemistry of the surface and deep fluids of the Miravalles volcano geothermal system (Costa Rica). Geothermics, 31, 91-128.

Graf, H. F., Feichter, J. \& Langmann, B. 1997. Volcanic sulfur emissions: estimates of source strength and its contribution to the global sulfate distribution. Journal of Geophysical Research-Atmospheres, 102, $10727-10738$.

Gustin, M. S. 2003. Are mercury emissions from geologic sources significant? A status report. Science of the Total Environment, 304, 153-167.

Gustin, M. S., LindberG, S. E. ET AL. 1999. Nevada SToRMS project: measurement of mercury emissions from naturally enriched surfaces. Journal of Geophysical Research, 104, $21831-21844$.

Gustin, M. S., Lindberg, S. E. \& Weisberg, P. J. 2008. An update on the natural sources and sinks of atmospheric mercury. Applied Geochemistry, 23, 482-493.

Halmer, M. M., SChmincKe, H. U. \& Graf, H. F. 2002. The annual volcanic gas input into the atmosphere, in particular into the stratosphere: a global data set for the past 100 years. Journal of Volcanology and Geothermal Research, 115, 511-528.

Henley, R. W. \& Berger, B. R. 2013. Nature's refineries - Metals and metalloids in arc volcanoes. Earth-Science Reviews, 125, 146-170.

Hinkley, T. K., Lamothe, P. J., Wilson, S. A., FinneGAN, D. L. \& Gerlach, T. M. 1999. Metal emissions from Kilauea, and a suggested revision of the estimated worldwide metal output by quiescent degassing of volcanoes. Earth and Planetary Science Letters, 170, $315-325$.

Jenner, F. E., O’Neill, H. C., Arculus, R. J. \& Mavrogenes, J. A. 2010. The magnetite crisis in the evolution of arc-related magmas and the initial concentration of $\mathrm{Au}, \mathrm{Ag}$, and $\mathrm{Cu}$. Journal of Petrology, 51, 2445-2464, http://dx.doi.org/10.1093/petrology/ egq063

Kantzas, E. P., McGonigle, A. J. S., Tamburello, G., Aiuppa, A. \& Bryant, R. G. 2010. Protocols for UV camera volcanic $\mathrm{SO}_{2}$ measurements. Journal of Volcanology and Geothermal Research, 94, 55-60, http:// dx.doi.org/10.1016/j.jvolgeores.2010.05.003

Kim, C. S., Brown, G. E. \& Rytuba, J. J. 2000. Characterization and speciation of mercury-bearing mine wastes using X-ray absorption spectroscopy. Science of the Total Environment, 261, 157-168.

KIM, K. H., Mishra, V. K. \& Hong, S. 2006. The rapid and continuous monitoring of gaseous elemental mercury (GEM) behavior in ambient air. Atmospheric Environment, 40, 3281-3293.

Kim, K. H., Shon, Z. H., Nguyen, H. T., Jung, K., PArK, C. G. \& BAE, G. N. 2011. The effect of man made source processes on the behavior of total gaseous mercury in air: a comparison between four urban monitoring sites in Seoul Korea. Science of the Total Environment, 409, 3801-3811.

Kyle, P. R., Meeker, M. \& Finnegan, D. 1990. Emission rates of sulfur dioxide, trace gases and metals from Mount Erebus, Antarctica. Geophysical Research Letters, 17, 2125-2128.

Labanieh, S., Chauvel, C., Germa, A. \& Quidelleur, X. 2012. Martinique: a clear case for sediment melting and slab dehydration as a function of distance to the trench. Journal of Petrology, 53, 2441-2464.

Langway, C. C., Osada, K., Clausen, H. B., Hammer, C. U. \& ShoJI, H. 1995. A 10-century comparison of prominent bipolar volcanic events in ice cores. Journal of Geophysical Research, 100, 16 241-16 247.

LindBerg, S., Bullock, R. ET AL. 2007. A synthesis of progress and uncertainties in attributing the sources of mercury in deposition. Ambio, 36, 19-32.

LindQvist, O. \& RodHe, H. 1985. Atmospheric mercury - a review. Tellus Series B-Chemical and Physical Meteorology, 37, 136-159.

Liu, S. L., Nadim, F., Perkins, C., Carley, R. J., Hoag, G. E., Lin, Y. H. \& Chen, L. T. 2002. Atmospheric mercury monitoring survey in Beijing, China. Chemosphere, 48, 97-107.

Lopes, R. (ed.) 2005. Volcanoes in Costa Rica. In: The Volcano Adventure Guide. Cambridge University Press, 286-292.

Madonia, P., Rizzo, A. L., Diliberto, I. S. \& Favara, R. 2013. Continuous monitoring of fumarole temperatures at Mount Etna (Italy). Journal of Volcanology and Geothermal Research, 257, 12-20, http://dx. doi.org/10.1016/j.jvolgeores.2013.03.001

Martin, R., Witt, M. L. I., Pyle, D. M., Mather, T. A., Watt, S. F. L., Bagnato, E. \& Calabrese, S. 2011. Rapid oxidation of mercury $(\mathrm{Hg})$ at volcanic vents: insights from high temperature thermodynamic models of Mt Etna's emissions. Chemical Geology, 283, 279-286.

Martin, R., WitT, M. L. I. ET AL. 2012. Bioindication of volcanic mercury $(\mathrm{Hg})$ deposition around Mt. Etna (Sicily). Chemical Geology, 310-311, 12-22.

Martínez, M. 2008. Geochemical evolution of the acid crater lake of Poás Volcano (Costa Rica): insights into volcanic-hydrothermal processes. Ph.D. thesis, University of Utrecht, the Netherlands.

Martínez, M., Fernández, E. ET AL. 2000. Chemical evolution and volcanic activity of the active crater lake of Poás volcano, Costa Rica, 1993-1997. 


\section{E. BAGNATO ET AL.}

Journal of Volcanology and Geothermal Research, 97, $127-141$

Mather, T. A., Witt, M. L. I. ET AL. 2012. Halogens and trace metal emissions from the ongoing 2008 summit eruption of Kilauea volcano, Hawaiì. Geochimica et Cosmochimica Acta, 83, 292-323.

McGonigle, A. J. S., Oppenheimer, C., Galle, B., Mather, T. A. \& Pyle, D. M. 2002. Walking traverse and scanning DOAS measurements of volcanic gas emission rates. Geophysical Research Letters, 29, 46-1-46-4, http://dx.doi.org/10.1029/2002GL0 15827

Melián, G. V., Pérez, N. M. ET AL. 2004. Emisión difusa de dióxido de carbono y vapor de mercurio en el volcán Miravalles, Costa Rica. Revista Geológica de América Central, 30, 179-188.

Melián, G. V., Galindo, I. ET AL. 2007. Diffuse emission of hydrogen from Poás Volcano, Costa Rica América Central. Pure and Applied Geophysics, 164, 2465-2487.

Morel, F. M. M., Kraepiel, A. M. L. \& Аmyot, M. 1998. The chemical cycle and bioaccumulation of mercury. Annual Review of Ecology, Evolution, and Systematics, 29, 543-566.

Mori, T. \& Burton, M. 2006. The $\mathrm{SO}_{2}$ camera: a simple, fast and cheap method for ground-based imaging of $\mathrm{SO}_{2}$ in volcanic plumes. Geophysical Research Letters, 33, L24804, http://dx.doi.org/10.1029/2006 GL027916

Mungall, J. E. 2002. Roasting the mantle: slab melting and the genesis of major $\mathrm{Au}$ and $\mathrm{Au}$ rich $\mathrm{Cu}$ deposits. Geology, 30, 915-918.

NAKaGawa, R. 1999. Estimation of mercury emissions from geothermal activity in Japan. Chemosphere, 38, $1867-1871$.

Nriagu, J. O. 1989. A global assessment of natural sources of atmospheric trace metals. Nature, 338, 47-49.

Nriagu, J. \& PaCYNA, J. M. 1988. Quantitative assessment of worldwide contamination of air, water and soil, by trace metals. Nature, 33, 134-139.

Nriagu, J. \& Becker, C. 2003. Volcanic emissions of mercury to the atmosphere: global and regional inventories. Science of the Total Environment, 304, $3-12$.

Ohsawa, S., Sudo, Y. ET AL. 2003. Some geochemical features of Yudamari Crater Lake, Aso volcano, Japan. Geothermal Research Rep Kyushu University, 12, 62-65 (in Japanese with English abstract).

Ohsawa, S., SAITo, T. ET AL. 2010. Color change of lake water at the active crater lake of Aso volcano, Yudamari, Japan: is it in response to change in water quality induced by volcanic activity? Limnology, 11, 207-215

Pirrone, N., Cinnirella, S. ET AL. 2010. Global mercury emissions to the atmosphere from anthropogenic and natural sources. Atmospheric Chemistry and Physics Discussion, 10, 4719-4752.

Pyle, D. M. \& Mather, T. A. 2003. The importance of volcanic emissions for the global atmospheric mercury cycle. Atmospheric Environment, 3, 5115-5124.

Pyle, D. M. \& Mather, T. A. 2009. Halogens in igneous processes and their fluxes to the atmosphere and oceans from volcanic activity: a review. Chemical Geology, 263, $110-121$.
Robertson, D. E., Crecelius, E. A., Fruchter, J. S. \& LudWICK, J. D. 1977. Mercury emissions from geothermal power plants. Science, 196, 1094-1097, http://dx.doi.org/10.1126/science.860131

Robock, A. \& Free, M. P. 1995. Ice core as an index of global volcanism from 1850 to the present. Journal of Geophysical Research, 100, 11549-11567.

Robock, A. \& Oppenheimer, C. (eds) 2003. Volcanism and the Earth's Atmosphere. American Geophysical Union, Washington, Geophysical Monograph Series, 137.

Roos-Barraclough, F., Martinez-Cortizas, A., Garcia-Rodeja, E. \& Shotyk, W. 2002. A 14,500 year record of accumulation of atmospheric mercury in peat: volcanic signals, anthropogenic influences and a correlation to bromine accumulation. Earth and Planetary Science Letters, 202, 435-451.

Rutter, A. P., Schauer, J. J. et AL. 2008. A comparison of speciated atmospheric mercury at an urban center and an upwind rural location. Journal of Environmental Monitoring, 10, 102-108.

Rutter, A. P., SNyder, D. C. et al. 2009. In situ measurements of speciated atmospheric mercury and the identification of source regions in the Mexico City Metropolitan Area. Atmospheric Chemistry and Physics, 9, 207-220.

Schmidt, A., Carslaw, K. S. ET AL. 2012. Importance of tropospheric volcanic aerosol for indirect radiative forcing of climate. Atmospheric Chemistry and Physics, 12, 7321-7339, http://dx.doi.org/10.5194/ acp-12-7321-2012

Schroeder, W. H. \& Munthe, J. 1998. Atmospheric mercury - an overview. Atmospheric Environment, 32, 809-822.

Schroeder, W. H., Keeler, G., Kock, H., Roussel, P., ScNeEberger, D. \& Schaedlich, F. 1995. International field intercomparison of atmospheric mercury measurement methods. Water Air and Soil Pollution, 80, 611-620.

Schuster, P. F., Krabbenhoft, D. P. et al. 2002. Atmospheric mercury deposition during the last 270 years: a glacial ice core record of natural and anthropogenic sources. Environmental Science and Technology, 36, 2303-2310, http://dx.doi.org/10.1021/es0157503

Shinohara, H. \& Witter, J. B. 2005. Volcanic gases emitted during mild Strombolian activity of Villarica volcano, Chile. Geophysical Research Letters, 32, L20308, http://dx.doi.org/10.1029/2005 GL024131

Shinohara, H., Aiuppa, A., Giudice, G., Gurrieri, S. \& Liuzzo, M. 2008. Variation of $\mathrm{H} 2 \mathrm{O} / \mathrm{CO} 2$ and $\mathrm{CO} 2 /$ $\mathrm{SO} 2$ ratios of volcanic gases discharged by continuous degassing of Mt. Etna Volcano, Italy. Journal of Geophysical Research, 113, B09203, http://dx.doi.org/ 10.1029/2007JB005185

Shinohara, H., Yoshikawa, S. \& Miyabuchi, Y. 2010. Degassing of Aso Volcano, Japan through an Acid Crater Lake: Differentiation of Volcanic GasHydrothermal Fluids Deduced from Volcanic Plume Chemistry. American Geophysical Union, Fall Meeting 2010, San Francisco, abstract \#V23A-2387.

Shinohara, H., Yoshikawa, S. \& Miyabuchi, Y. 2013. Degassing activity of a volcanic crater lake: volcanic plume measurements at the Yudamari crater lake, 


\section{MERCURY FLUXES FROM VOLCANIC AND GEOTHERMAL SOURCES}

Aso volcano, Japan. In: Rouwet, D., TAssi, J. \& VANDEMEUlebroucK, J. (eds) Volcanic Lakes, Advances in Volcanology. Springer-Heidelberg, accepted.

Shishkina, T., Botcharnikof, R. E., Holtz, F., Almeev, R. R. \& Portnyagin, M. 2010. Solubility of $\mathrm{H}_{2} \mathrm{O}$ and $\mathrm{CO}_{2}$-beraing fluids in tholeiitic basalts at pressures up to $500 \mathrm{MPa}$. Chemical Geology, 177, $115-125$.

Sholupov, S., Pogarev, S., Ryzhov, V., Mashyanov, N. \& Stroganov, A. 2004. Zeeman atomic absorption spectrometer RA-915+ for direct determination of mercury in air and complex matrix samples. Fuel Processing Technology, 85, 473-485.

Siegel, S. M. \& Siegel, B. Z. 1984. First estimate of annual mercury flux at the Kilauea main vent. Nature, 309, 146-147.

SIMPSON, D., WiNIWARTER, W. ET AL. 1999. Inventorying emissions from nature in Europe. Journal of Geophysical Research, 104, 8113-8152.

Slemr, F., Schuster, G. \& SeIler, W. 1985. Distribution, speciation, and budget of atmospheric mercury. Journal of Atmospheric Chemistry, 3, 407-434.

Sonke, J. E., Zambardi, T. \& Toutain, J. P. 2008. Indirect gold trap MC-ICP-MS coupling for $\mathrm{Hg}$ stable isotope analysis using a syringe injection interface. Journal of Analytical Atomic Spectrometry, 23, $569-573$.

Sprovieri, F., Pirrone, N., Ebinghaus, R., Kock, H. \& Dommergue, A. 2010. A review of worldwide atmospheric mercury measurements. Atmospheric Chemistry and Physics, 10, 8245-8265.

StraCKE, A. 2012. Earth's heterogeneous mantle: a product of convection-driven interaction between crust and mantle. Chemical Geology, 330-331, 274-299.

Symonds, R. B., ReEd, M. H. \& Rose, W. I. 1992. Origin, speciation, and fluxes of trace-element gases at Augustine volcano, Alaska: insights into magma degassing and fumarolic processes. Geochimica et Cosmochimica Acta, 56, 633-657.

Symonds, R. B., Gerlach, T. M. \& Reed, M. H. 2001. Magmatic gas scrubbing: implications for volcano monitoring. Journal of Volcanology and Geothermal Research, 108, 303-341.

Tamburello, G., McGonigle, A. J. S., Kantzas, E. P. \& AiUPPA, A. 2011. Recent advances in ground-based ultraviolet remote sensing of volcanic $\mathrm{SO}_{2}$ fluxes. Annals of Geophysics, 54, 199-208, http://dx.doi. org/10.4401/ag-5181

Taran, Y. A., Pilipenko, V. P., Rozhkov, A. M. \& VAKIN, E. A. 1992. A geochemical model for fumaroles of the Mutnovsky volcano, Kamchatka. USSR Journal of Volcanology and Geothermal Research, 49, 269-283.

TASSI, F., VASElli, O. ET AL. 2005. The hydrothermalvolcanic system of Rincon de la Vieja volcano Costa Rica): a combined (inorganic and organic) geochemical approach to understanding the origin of the fluid discharges and its possible application to volcanic surveillance. Journal of Volcanology and Geothermal Research, 148, 315-333.
Terada, A. \& Sudo, Y. 2012. Thermal activity within the western slope geothermal zone of Aso volcano, Japan: development of a new thermal area. Geothermics, 42, 56-64.

Unni, C., Fitzgerald, W. F., Settle, D., Gill, G., Ray, B., Patterson, C. C. \& Duce, R. 1978. The impact of volcanic emissions on the global atmospheric cycles of sulfur, mercury and lead. EOS Transaction, American Geophysical Union, 59, 1223.

VareKamp, J. C. \& Buseck, P. R. 1981. Mercury emissions from Mount St Helens during September 1980. Nature, 293, 555-556.

VAREKAMP, J. C. \& BuSECK, P. R. 1986. Global mercury flux from volcanic and geothermal sources. Applied Geochemistry, 1, 65-73.

Vaselli, O., Tassi, F., Duarte, E., Fernandez, E., Poreda, R. J. \& Delgado Huertas, A. 2010. Evolution of fluid geochemistry at the Turrialba volcano (Costa Rica) from 1998 to 2008. Bulletin of Volcanology, 72, 397-410, http://dx.doi.org/10.1007/s00445009-0332-4

VON GLASGOW, R. 2010. Atmospheric chemistry in volcanic plumes. PNAS, 107, 6594-6599.

Wallace, P. J. 2005. Volatiles in subduction zone magmas: concentrations and fluxes based on melt inclusions and volcanic gas data. Journal of Volcanology and Geothermal Research, 140, 217-240.

Wardell, L. J., Kyle, P. R. \& Counce, D. 2008. Volcanic emissions of metals and halogens from White Island (New Zealand) and Erebus volcano (Antarctica) determined with chemical traps. Journal of Volcanology and Geothermal Research, 177, 734-742.

Weissberg, B. G. \& Rodhe, A. G. 1978. Mercury in some New Zealand geothermal discharges. New Zealand Journal of Science, 21, 365-369.

Witt, M. L. I., Mather, T. A., Pyle, D. M., Aiuppa, A., Bagnato, E. \& Tsanev, V. I. 2008a. Mercury and halogen emissions from Masaya and Telica volcanoes, Nicaragua. Journal of Geophysical Research, 113, B06203, http://dx.doi.org/10.1029/2007JB00 5401

Witt, M. L. I., Fischer, T. P., Pyle, D. M., Yang, T. F. \& Zellmer, G. F. 2008b. Fumarole compositions and mercury emissions from the Tatun Volcanic field, Taiwan: results from multi-component gas analyser, portable mercury spectrometer and direct sampling techniques. Journal of Volcanology and Geothermal Research, 178, 636-643.

Zambardi, T., Sonke, J. E., Toutain, J. P., Sortino, F. \& Shinohara, H. 2009. Mercury emissions and stable isotopic compositions at Vulcano Island (Italy). Earth and Planetary Science Letters, 277, 236-243, http://dx.doi.org/10.1016/j.epsl.2008.10.023

Zimmer, M. M., Fischer, T. P., Hilton, D. R., Alvarado, G. E., Sharp, Z. D. \& Walker, J. A. 2004. Nitrogen systematics and gas fluxes of subduction zones: insights from Costa Rica arc volatiles. Geochemistry Geophysics Geosystems, 5, http://dx.doi.org/10. 1029/2003GC000651 